\title{
Phenotype and function of nasal dendritic cells
}

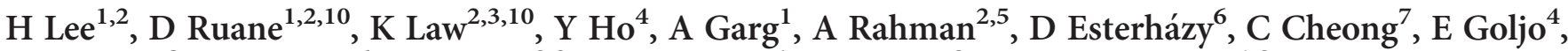 \\ AG Sikora ${ }^{8}$, D Mucida $^{6}$, BK Chen ${ }^{2,3}$, S Govindraj $^{4}$, G Breton ${ }^{9}$ and S Mehandru ${ }^{1,2}$
}

Intranasal (i.n.) vaccination generates immunity across local, regional, and distant sites. However, nasal dendritic cells (DCs), pivotal for the induction of i.n. vaccine-induced immune responses, have not been studied in detail. Here, by using a variety of parameters, we define nasal DCs in mice and humans. Distinct subsets of "classical" DCs, dependent on the transcription factor zbtb46 were identified in the murine nose. The murine nasal DCs were Fms-related tyrosine 3 kinase ligand responsive and displayed unique phenotypic and functional characteristics, including the ability to present antigen, induce an allogeneic T-cell response, and migrate in response to lipopolysaccharide or live bacterial pathogens. Importantly, in a cohort of human volunteers, BDCA-1 + DCs were observed to be the dominant nasal DC population at steady state. During chronic inflammation, the frequency of both BDCA-1 ${ }^{+}$and BDCA-3 ${ }^{\text {hi }}$ DCs was reduced in the nasal tissue, associating the loss of these immune sentinels with chronic nasal inflammation. The present study is the first detailed description of the phenotypic, ontogenetic, and functional properties of nasal DCs, and will inform the design of preventative immunization strategies as well as therapeutic modalities against chronic rhinosinusitis.

\section{INTRODUCTION}

Dendritic cells (DCs) have a pivotal role in immune homeostasis, marshaling immunity against pathogens, while maintaining tolerance to commensals. The nasal associated lymphoid tissue (NALT) serves as a site for the induction of nasal, ${ }^{1,2}$ pharyngeal, ${ }^{3}$ respiratory, ${ }^{4}$ oral, ${ }^{2}$ gastrointestinal, ${ }^{5,6}$ genitourinary, ${ }^{7,8}$ and systemic ${ }^{9}$ immunity. Therefore, it follows that the nose should contain a significant population of DCs capable of priming and disseminating immune responses. However, nasal DCs have not yet been characterized and are the focus of the present study.

The murine NALT consist of paired lymphoid structures, resting on the nasal surface of the soft palate on either side of the nasal septum. ${ }^{10-12}$ The NALT is covered by follicleassociated epithelium ${ }^{13}$ interspersed with $\mathrm{M}$ cells, ${ }^{14-16}$ goblet cells, ${ }^{17,18}$ and intra-epithelial lymphocytes. ${ }^{19}$ Within the NALT, B cells predominate over T cells at steady state, ${ }^{7,20,21}$ with $\operatorname{IgD}^{+}$and $\operatorname{IgM}^{+} \mathrm{B}$ cells constitutively present and $\operatorname{IgA}^{+} \mathrm{B}$ cells readily inducible following intranasal (i.n.) vaccination. ${ }^{8,22}$
Among $\mathrm{T}$ cells, Th $0 \mathrm{CD} 4^{+} \mathrm{T}$ cells, $\mathrm{CD} 8{ }^{+} \alpha \alpha, \mathrm{CD} 8^{+} \alpha \beta$, and $\mathrm{CD}^{+} \gamma \delta \mathrm{T}$ cells have been described in the NALT, with $\mathrm{CD} 4^{+}$ $\mathrm{T}$ cells predominating over $\mathrm{CD} 8{ }^{+} \mathrm{T}$ cells at steady state. ${ }^{19,23,24}$ Although structural similarities between the NALT and Peyer's patches are noted, ${ }^{21,23}$ important differences exist with regards to development ${ }^{13}$ and lymphocyte homing. ${ }^{25,26}$

DCs initiate the adaptive immune response. ${ }^{27}$ Since the initial description of DCs as "CD11c cells", we have come to recognize the complexity and lineage diversity of DCs in various tissues. ${ }^{28,29}$ Among the nasal DCs, although studies have alluded to $\mathrm{CD} 11 \mathrm{c}^{+}$cells in the NALT, ${ }^{20,30}$ there are no descriptions of DC phenotype, subsets, or function.

Here, by using a variety of assays, we have defined the morphology, phenotype, ontogeny, and function of mouse nasal DCs. In doing so, we demonstrate the complexity of nasal DCs and their behavior in the face of inflammatory stimuli such as lipopolysaccharide (LPS). In addition, we have examined putative DC subsets in surgically resected human nasopharyngeal tissue from normal volunteers as well as patients with

\footnotetext{
${ }^{1}$ Division of Gastroenterology, Department of Medicine, Icahn School of Medicine at Mount Sinai, New York, New York, USA. ${ }^{2}$ Immunology Institute, Icahn School of Medicine at Mount Sinai, New York, New York, USA. ${ }^{3}$ Division of Infectious Diseases, Department of Medicine, Icahn School of Medicine at Mount Sinai, New York, New York, USA. ${ }^{4}$ Department of Otorhinolaryngology, Icahn School of Medicine at Mount Sinai, New York, New York, USA. ${ }^{5}$ Flow Cytometry Shared Resource Facility, Icahn School of Medicine, New York, New York, USA. 'aboratory of Mucosal Immunology, Rockefeller University, New York, New York, USA. ${ }^{7}$ Laboratory of Cellular Immunology and Physiology, Institut de Recherches Cliniques de Montréal and Department of Microbiology and Immunology, Université de Montréal, Montreal, Quebec, Canada. ${ }^{8}$ Bobby R. Alford Department of Otolaryngology-Head and Neck Surgery, Baylor College of Medicine, Houston, Texas, USA and ${ }^{9}$ Laboratory of Molecular Immunology, Rockefeller University, New York, New York, USA. Correspondence: S Mehandru (Saurabh.mehandru@mssm.edu)

${ }^{10}$ These authors contributed equally to this work.
} 
chronic rhinosinusitis (CRS). The data presented herein are the first description of nasal DCs and will inform the design of novel i.n. vaccines for prevention and treatment of diseases.

\section{RESULTS}

\section{Morphology of nasal DCs in mice}

The NALT were identified on the nasal surface of the palate, between the incisors and first molar teeth as tridimensional, oval structures on hematoxylin and eosin staining. Higher magnification $(\times 400)$ revealed aggregates of mononuclear cells, populating the NALT (Figure 1a). To further study these mononuclear cells, nasal cryosections were stained with combinations of fluorescent antibodies identifying putative $\mathrm{CD}_{11 \mathrm{c}^{+}} \mathrm{DCs} \mathrm{CD}^{+}{ }^{+} \mathrm{T}$ cells, and $\mathrm{B} 220^{+} \mathrm{B}$ cells. Respective isotype controls confirmed the specificity of staining (data not shown). Distinct T and B areas were noted in the NALT as reported previously. ${ }^{30}$ Notably, DCs were predominantly seen in the T-cell areas or in the periphery of the NALT (Figure 1b). Three-dimensional imaging using two-photon microscopy revealed a high density of $\mathrm{CD}_{11 \mathrm{c}-\mathrm{eYFP}}{ }^{+}$cells uniformly distributed on the NALT surface (Figure 1c). The majority of $\mathrm{CD}_{11 \mathrm{c}-\mathrm{eYFP}}{ }^{+}$cells were embedded among collagen fibers visualized by second harmonic generation and displayed numerous dendrites (Supplementary Figure S1 online). However, on deeper imaging through the NALT, CD11c$\mathrm{eYFP}^{+}$cells reduced in frequency and showed a less ruffled and condensed morphology (data not shown). To further study the peripherally distributed $\mathrm{CD} 11 \mathrm{c}^{+}$cells, nasal sections were double-labeled with anti-mouse keratin 18 and CD11c. A dense network of $\mathrm{CD} 11 \mathrm{c}^{+}$cells was found subjacent to the epithelium (Figure 1d). Fortuitously, in some of the sections we detected that nasal DCs were extending dendrites across the nasal epithelium, into the lumen of the nose (Figure 1d). As extension of DC dendrites was observed infrequently, we are unable to quantify this in the present study. We next studied the association of nasal $\mathrm{CD} 11 \mathrm{c}^{+}$cells with blood vessels (antiPECAM-1) and lymphatic channels (anti-LYVE-1), and found nasal DCs clustering with lymphatic vessels in the posterior aspects of the NALT (Figure 1e) as well as the blood vessels distributed throughout the NALT (Figure 1f). Thus, a high density of putative DCs, positioned to sample the airway antigens, was noted within the murine nose.

\section{Phenotypic characterization of murine nasal DCs identifies distinct subsets of myeloid DCs}

Using multi-parameter flow cytometry, we first examined DCs from the entire nose and gated on live, $\mathrm{CD} 45^{+}$, lymphocyte lineage-negative, $\mathrm{CD} 11 \mathrm{c}^{+} \mathrm{MHCII}^{+}$cells isolated from mechanically disrupted and collagenase-digested whole nasal tissue. Three distinct populations of putative DCs could be identified using anti-CD103 and anti-CD11b antibodies: $\mathrm{CD}_{103}{ }^{+} \mathrm{CD} 11 \mathrm{~b}^{-}$cells, $\mathrm{CD} 11 \mathrm{~b}^{+} \mathrm{CD} 103^{-}$cells, and $\mathrm{CD} 103^{+}$ $\mathrm{CD}_{11} \mathrm{~b}^{+}$double-positive cells (Figure 2a), with $\mathrm{CD} 11 \mathrm{~b}^{+}$ $\mathrm{CD}_{103^{-}}{ }^{-}$cells being the predominant population. However, $\mathrm{CD}_{11 \mathrm{~b}^{+}} \mathrm{CD}_{103}{ }^{-}$cells are heterogeneous and comprise both classical DCs (cDCs) and macrophages (M $\phi)$. CD64 (Fc $\gamma \mathrm{R} 1)$ has been shown to recognize $\mathrm{M} \phi$ selectively ${ }^{7,26,31,32}$ and can help distinguish $\mathrm{cDC}$ from $\mathrm{M} \phi$ within $\mathrm{CD} 103^{-} \mathrm{CD} 11 \mathrm{~b}^{+}$cells.

We initially tested the expression of CD64 and heat-stable antigen or CD24, an important co-stimulatory molecule for the induction of T-helper cells, ${ }^{33}$ on $\mathrm{CD} 11 \mathrm{c}^{+} \mathrm{MHCII}^{+}$gated $\mathrm{CD}_{103}{ }^{-} \mathrm{CD} 11 \mathrm{~b}^{+} \mathrm{F} 4 / 80^{+}$cells. As shown in Supplementary Figure S2, the $\mathrm{CD} 103^{-} \mathrm{CD} 11 \mathrm{~b}^{+} \mathrm{F} 4 / 80^{+}$cells contained both $\mathrm{CD} 24^{+}$and $\mathrm{CD} 24^{-}$cells. Further analyses revealed that the $\mathrm{CD} 4^{+}$cells were contained within the $\mathrm{CD} 11 \mathrm{~b}^{+} \mathrm{F} 4 / 80^{+}$cells, while both $\mathrm{CD}_{11 \mathrm{~b}}{ }^{+} \mathrm{F} 4 / 80^{-}$and $\mathrm{CD}_{103}{ }^{+} \mathrm{CD} 11 \mathrm{~b}^{-}$cells lacked CD64 expression (data not shown). These data indicated $\mathrm{CD}_{11 \mathrm{c}^{+}} \mathrm{MHCII}^{+}$gated $\mathrm{CD} 103^{-} \mathrm{CD}^{-} 1 \mathrm{~b}^{+}$cells within the nose contain both $\mathrm{CDC}$ and $\mathrm{M} \phi$, which could be defined as $\mathrm{CD}^{-} 4^{-} \mathrm{F} 4 / 80^{-} \mathrm{CDC}$ and $\mathrm{CD} 64^{+} \mathrm{F} 4 / 80^{+} \mathrm{M} \phi$ (Figure 2a). In addition, plasmacytoid DCs were identified among $\mathrm{MHCII}{ }^{-}$nasal cells as PDCA- ${ }^{\text {hi }} \mathrm{CD} 11 \mathrm{c}^{+} \mathrm{B} 220^{+}$cells (Figure 2a). The total number of cells contained within each of the DC subsets are quantified in Figure 2b. Next, we examined DCs in the inductive (NALT) and effector (nasal passages) sites of nose separately. As expected, the density of putative DCs was significantly greater in the NALT tissue compared with that in the nasal passages. Interestingly, the $\mathrm{CD}_{103}{ }^{+} \mathrm{CD} 11 \mathrm{~b}^{+}$cells were predominantly found in the nasal passages, while both the NALT and non-NALT tissue contained $\mathrm{CD} 103^{+} \mathrm{CD} 11 \mathrm{~b}^{-}$and $\mathrm{CD}_{103}{ }^{-} \mathrm{CD}_{11 b^{+}}$cells (Figure 2c). Confocal images from CD11c-eYFP mice confirmed that eYFP ${ }^{+}$DCs were present in non-NALT nasal mucosa (Figure 2d).

A detailed phenotypic assessment of each of the putative DC subsets was performed next (Figure 2e). Interestingly, all subsets of nasal $\mathrm{CD} 11 \mathrm{c}^{+} \mathrm{MHCII}^{+}$cells lacked CD8 $\alpha$. Although both the $\mathrm{CD}_{103}{ }^{+} \mathrm{CD} 11 \mathrm{~b}^{-}$and $\mathrm{CD} 103^{+} \mathrm{CD} 1 \mathrm{~b}^{+}$cells were $\mathrm{CD} 24^{\mathrm{hi}}$, among the $\mathrm{CD} 11 \mathrm{~b}^{+}$cells the $\mathrm{CD} 64^{+} \mathrm{F} 4 / 80^{+}$and CD $64^{-} \mathrm{F} 4 / 80^{+}$subsets were predominantly $(\sim 90 \%$ cells $)$ $\mathrm{CD} 24^{-}$. In contrast, $\mathrm{CD} 64^{-} \mathrm{F} 4 / 80^{-}$cells contained equal numbers of $\mathrm{CD} 24^{+}$and $\mathrm{CD} 24^{-}$cells. CD115 was not expressed by any of the nasal $\mathrm{CD} 11 \mathrm{c}^{+} \mathrm{MHCII}^{+}$subsets. Further, the $\mathrm{CD}_{103}{ }^{+} \mathrm{CD} 11 \mathrm{~b}^{-}$cells were negative for macrophage mannose receptor $\mathrm{CD} 206$, while $\mathrm{CD} 11 \mathrm{~b}^{+} \mathrm{CD} 103^{+}$cells were $\mathrm{CD} 206^{\text {int }}$. Among the $\mathrm{CD} 11 \mathrm{~b}$ subsets, $\mathrm{CD} 64^{+} \mathrm{F} 4 / 80^{+}$ cells were CD206 ${ }^{\mathrm{hi}}$, both $\mathrm{CD} 64^{-} \mathrm{F} 4 / 80^{+}$and $\mathrm{CD} 64^{-} \mathrm{F} / 40^{-}$ cells were $\mathrm{CD} 206^{\text {lo }}$ to $\mathrm{CD} 206^{\text {int }}$. $\mathrm{CD} 103^{+} \mathrm{CD} 11 \mathrm{~b}^{-}$, and $\mathrm{CD}_{103}{ }^{+} \mathrm{CD}_{11 \mathrm{~b}}{ }^{+}$cells were $\mathrm{EpCAM}^{\text {hi }}$, while the $\mathrm{CD} 11 \mathrm{~b}^{+}$ subsets contained both $\mathrm{EpCAM}^{\mathrm{hi}}$ and $\mathrm{EpCAM}^{\text {lo }}$ cells. Finally and expectedly, LPS receptor, CD14, was expressed by the $\mathrm{CD}_{11 b^{+}} \mathrm{CD}_{64}{ }^{+} \mathrm{F} 4 / 80^{+}$cells as well as $\mathrm{CD} 11 \mathrm{~b}^{+} \mathrm{CD} 64^{-}$ $\mathrm{F} 4 / 80^{+}$cells, while the $\mathrm{CD} 11 \mathrm{~b}^{+} \mathrm{CD} 64^{-} \mathrm{F} 4 / 80^{-}$cells contained both $\mathrm{CD} 14^{+}$and $\mathrm{CD} 14^{-}$cells. In contrast, $\mathrm{CD} 103^{+}$ $\mathrm{CD}_{11 b^{-}}$cells were CD14 negative.

Collectively, these data show that among the CD11c ${ }^{+}$ $\mathrm{MHCII}^{+}$nasal cells, we could identify five distinct populations of antigen presenting cells: (a) $\mathrm{CD}_{103}{ }^{+} \mathrm{CD} 11 \mathrm{~b}^{-}$cells expressing phenotypic markers associated with $\mathrm{CD}_{103}{ }^{+}$ $\mathrm{DC},{ }^{34}$ (b) the $\mathrm{CD}_{103}{ }^{-} \mathrm{CD} 11 \mathrm{~b}^{+}$cells, a heterogeneous population, comprising three distinct subsets-(i) $\mathrm{CD} 64^{+} \mathrm{F} 4 / 80^{+}$ cells that had the phenotypic markers associated with $\mathrm{M} \phi$, (ii) $\mathrm{CD} 64^{-} \mathrm{F} 4 / 80^{-}$cells that had markers associated with 

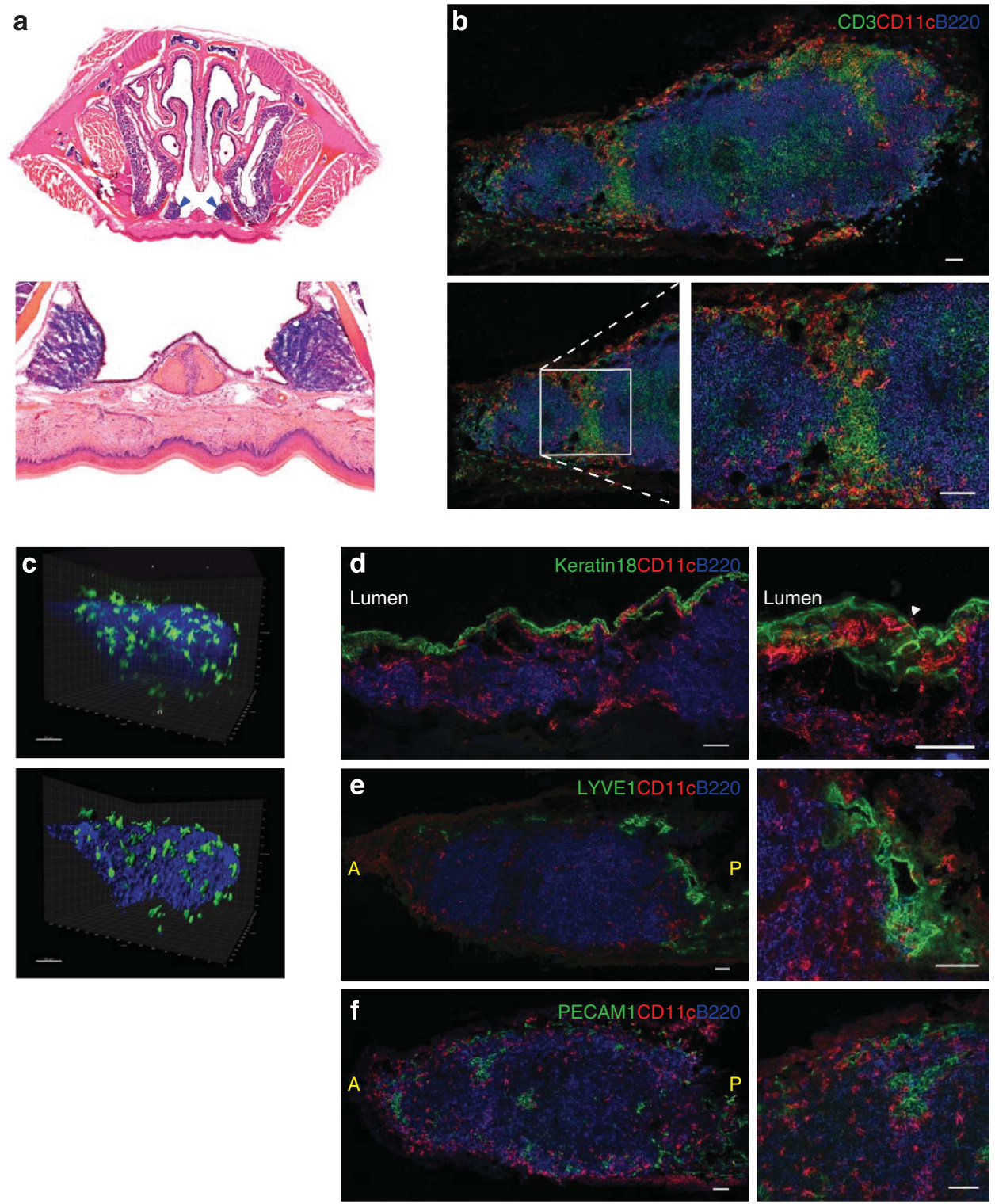

Figure 1 Dendritic cells (DCs) in murine nasal-associated lymphoid tissue (NALT). (a) Hematoxylin and eosin (H\&E) staining was used to define the morphology of murine NALT (indicated with blue arrowheads) at $\times 200$ original magnification (top) and at $\times 400$ original magnification (bottom). (b) Immunofluorescent staining to define the relationship of NALT-associated DCs with T and B cells. Confocal micrograph of the entire longitudinal section of NALT is depicted here by combining individual images in Adobe Photoshop CC. CD3 ${ }^{+} \mathrm{T}_{\text {cells }}$ (green), B220 ${ }^{+} \mathrm{B}$ cells (blue), and $\mathrm{CD} 11 \mathrm{c}^{+}$cells (red) are shown. Inset highlights a magnified area demonstrating that the $\mathrm{CD} 11 \mathrm{c}^{+}$cells are predominantly located in the $\mathrm{T}$ cell zones and in the periphery of the NALT. Each figure is representative of at least five experiments. Bars $=50 \mu \mathrm{m}$. (c) Three-dimensional reconstruction from two-photon microscopy data showing spatial distribution of nasal CD11c ${ }^{+}$cells (green) from enhanced yellow fluorescent protein (eYFP) transgenic mice and collagen second harmonic generation (blue). Raw fluorescent image (top) and reconstructed image (bottom) are depicted. (d-f) Immunofluorescent staining to define the relationship of NALT DCs with the nasal epithelium, blood vessels, and lymphatic channels. (d) The relationship of $\mathrm{CD}_{11 \mathrm{c}^{+}}$cells (red) with the cytokeratin $18^{+}$nasal epithelial cells (green) and $\mathrm{B}^{2} 2 \mathrm{O}^{+} \mathrm{B}$ cells (blue). White arrowhead shows the extension of $\mathrm{CD}_{11 \mathrm{c}^{+}}$dendrites across the epithelium into the nasal lumen. (e) The relationship of CD11c ${ }^{+}$cells (red) with LYVE1 ${ }^{+}$lymphatic channels (green) and $\mathrm{B}_{220^{+}} \mathrm{B}$ cells (blue). (f) The proximity of $\mathrm{CD} 11 \mathrm{c}^{+}$cells (red) to PECAM1 ${ }^{+}$blood vessels (green) and B220 ${ }^{+} \mathrm{B}$ cells (blue). In d, e, and f, confocal micrographs of the entire longitudinal section of NALT are depicted by combining individual images in Adobe Photoshop CC. A, anterior; P, posterior. Each figure is representative of at least three experiments. Bars $=50 \mu \mathrm{m}$.

$\mathrm{CD} 11 \mathrm{~b}^{+} \mathrm{cDCs}$, and (iii) $\mathrm{CD} 64^{-} \mathrm{F} 4 / 80^{+}$cells that appeared to have both $\mathrm{M} \phi$ - and cDC-like cells. (c) Finally, the nose also contained $\mathrm{CD}_{103}{ }^{+} \mathrm{CD} 11 \mathrm{~b}^{+}$cells that shared phenotypic characteristics of both $\mathrm{CD}_{103}{ }^{+} \mathrm{DC}$ and $\mathrm{CD} 11 \mathrm{~b}^{+} \mathrm{DC}$.

We next identified the morphological characteristics of putative nasal DCs and nasal M $\phi$. Wright-Geimsa staining of cytospins of the fluorescence-activated cell-sorted nasal DCs (defined as $\mathrm{MHCII}^{+} \mathrm{CD} 11 \mathrm{c}^{+} \mathrm{F} 4 / 80^{-} \mathrm{CD}^{-} 4^{-}$cells based on the criteria defined above) as well as putative nasal $\mathrm{M} \phi$ (defined as $\mathrm{MHCII}^{+} \mathrm{CD} 11 \mathrm{c}^{+} \mathrm{F} 4 / 80^{+} \mathrm{CD}^{+} 4^{+}$cells) revealed clear morphological differences. Although nasal DCs had abundant cytoplasm and "dendrites," nasal M $\phi$ showed an eccentric, 


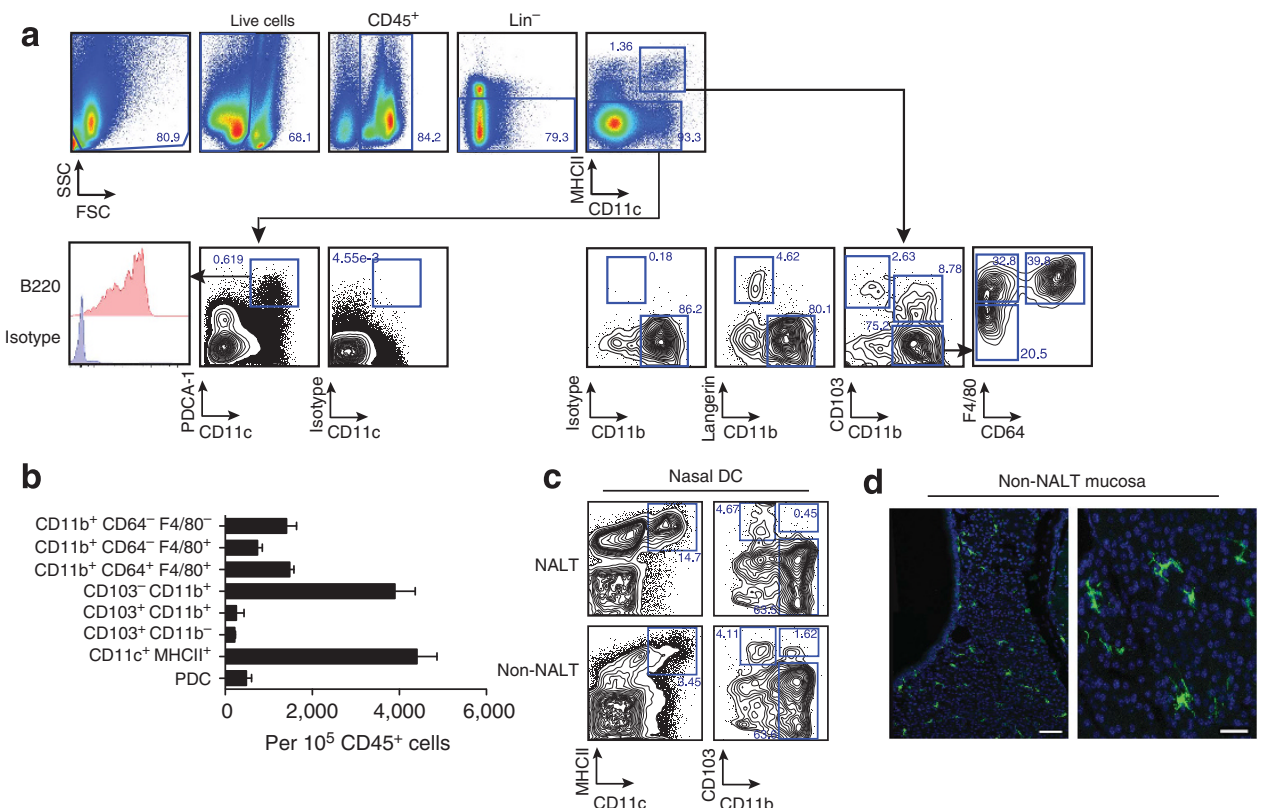

e

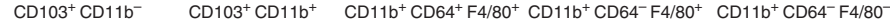

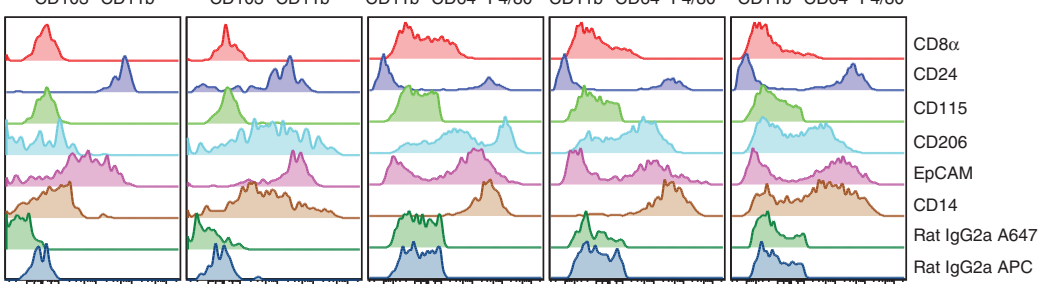

f

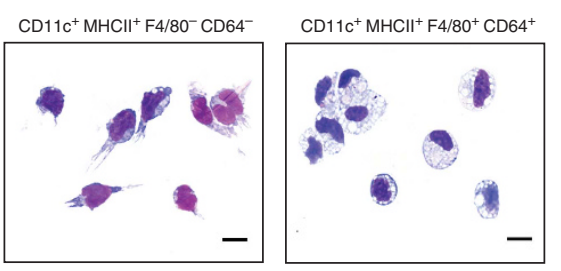

$\mathrm{CD}_{11 \mathrm{c}^{+} \mathrm{MHCII}}{ }^{+} \mathrm{F} 4 / 80^{+} \mathrm{CD}^{-}$

g
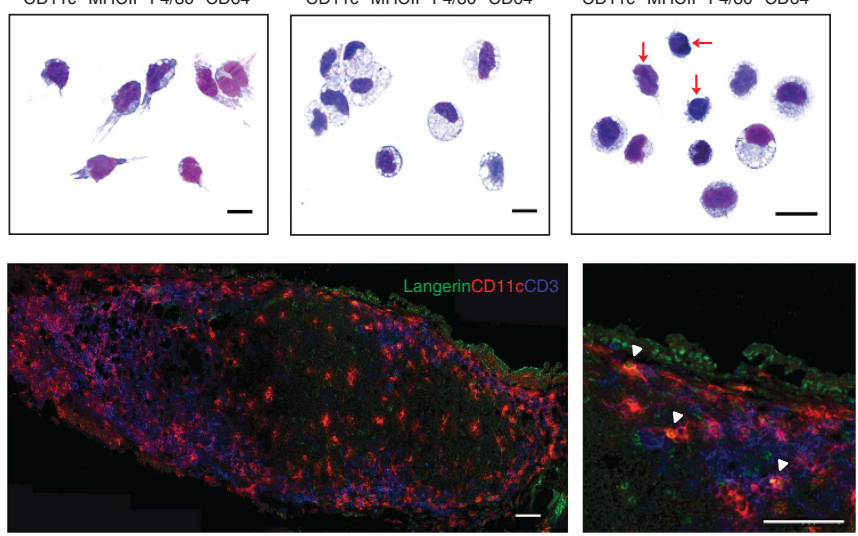

Figure 2 Phenotypic characterization of nasal dendritic cells (DCs). (a,b,c) Single-cell suspension of nasal cells was obtained by mechanical disruption and collagenase digestion of nasal tissue. Multiparameter flow cytometry was used to identify DC subsets within the murine nose. (a) The gating strategy used to delineate myeloid DC (mDC) subsets based on the expression of CD103, CD11b, and CD64 on live,

$\mathrm{CD}^{+} 5^{+}$lineage ${ }^{-} \mathrm{CD} 11 \mathrm{c}^{+} \mathrm{MHCII}^{+}$cells. For identification of plasmacytoid DCs (pDCs), $\mathrm{MHClI}^{-}$cells were defined on the basis of CD11c and PDCA-1 staining. PDCA- ${ }^{\text {hi }} \mathrm{CD} 11 \mathrm{c}^{+} \mathrm{B} 220^{+}$cells were deemed putative $\mathrm{pDCs}$. (b) Absolute number of all DC subsets including pDCs. Error bars $=\mathrm{s}$.d.

(c) Identification of nasal associated lymphoid tissue (NALT) and non-NALT DCs separately. (d) eYFP ${ }^{+}$cells in non-NALT mucosa. Bars $=50 \mu m$ (left) and $25 \mu \mathrm{m}$ (right). (e) Detailed phenotypic characterization of the nasal antigen presenting cell (APC) subsets using a panel of monoclonal antibodies. (f) Wright-Geimsa stains were used to define the cellular morphology of putative nasal DCs and nasal M $\phi$. Bars $=10 \mu \mathrm{m}$. (g) CD11 ${ }^{+}$langerin ${ }^{+}$DCs were analyzed by immunofluorescence using confocal microscope where langerin ${ }^{+}$cells are depicted in green, CD11 ${ }^{+}$cells in red, and CD $3^{+}$ cells in blue. White arrowheads indicate the cells where co-localization of langerin with CD11c was observed. Bars $=50 \mu \mathrm{m}$.

reniform nucleus with intracellular granules and lack of significant membrane extensions or dendrites. Further, as the $\mathrm{CD} 11 \mathrm{c}^{+} \mathrm{MHCII}{ }^{+} \mathrm{CD} 64^{-} \mathrm{F} 4 / 80^{+}$cells were a major population (Figure 2a), we examined them separately as well.
Although a majority of $\mathrm{CD} 11 \mathrm{c}^{+} \mathrm{MHCII}{ }^{+} \mathrm{CD} 64^{-} \mathrm{F} 4 / 80^{+}$cells displayed the morphology of $\mathrm{M} \phi$ with a granulated cytoplasm and reniform nucleus, cells with cytoplasmic extensions and less vacuolated cytoplasm, cells resembling DCs could also be 
seen (Figure 2f). Thus, the $\mathrm{CD} 11 \mathrm{c}^{+} \mathrm{MHCII}^{+} \mathrm{CD}^{-} 4^{-} \mathrm{F} 4 / 80^{+}$ cells were a mixed population comprising both $\mathrm{M} \phi$ and DCs.

Finally, we wanted to determine the location $\mathrm{CD} 103^{+}$ $\mathrm{CD} 11 \mathrm{~b}^{-}$cells within the NALT. As $\mathrm{CD} 103^{+} \mathrm{CD} 11 \mathrm{~b}^{-}$cells exclusively expressed langerin, we used a combination of antibodies specific to CD11c, langerin, and CD103, to denote putative $\mathrm{CD} 103^{+}$DCs in the NALT. The frequency of langerin $^{+}$cells that co-labeled with $\mathrm{CD} 11 \mathrm{c}$ was rare. When found, the langerin ${ }^{+} \mathrm{CD} 11 \mathrm{c}^{+}$cells were mostly located toward the periphery of the NALT (Figure 2g), consistent with the expression of epithelial cell adhesion molecule (EpCAM) by these cells, as noted by flow cytometry.

\section{FLT3 ligand expands $\mathrm{CD}_{103}{ }^{+} \mathrm{CD}_{11 \mathrm{~b}}{ }^{-}$nasal DCs and $\mathrm{CD} 103^{-} \mathrm{CD}^{-11 b^{+}}{ }^{\mathrm{F}} 4 / 80^{-} \mathrm{CD}^{-} 4^{-}$nasal DCs}

Fms-related tyrosine 3 kinase (FLT3) ligand, a key cytokine in DC differentiation, ${ }^{35}$ has also been used as a potent adjuvant in nasally administered vaccines. ${ }^{29,33,36}$ To determine the effect of FLT3 ligand on nasal DCs, we implanted mice with $5-7 \times 10^{6}$ B16-FLT3L melanoma (B16-FLT3L) cells ${ }^{37}$ and used mice implanted with B16 melanoma (B16) cells or wild-type (WT) mice as controls. Nasal CD11 ${ }^{+} \mathrm{MHCII}^{+}$cells were increased 12-fold in the B16-FLT3L mice compared with WT or B16 mice

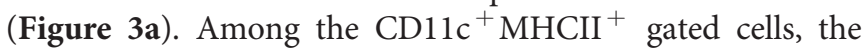
frequency of all nasal DC subsets was increased in B16-FLT3L mice, with $\mathrm{CD} 103^{+} \mathrm{CD}_{11 \mathrm{~b}}{ }^{-}$cells and $\mathrm{CD} 103^{-} \mathrm{CD} 11 \mathrm{~b}^{+}$cells showing the most appreciable increase in numbers (Figures 3a,b). Among the $\mathrm{CD} 103^{-} \mathrm{CD}_{11 b^{+}}$gated cells, a dramatic expansion in $\mathrm{CD} 11 \mathrm{~b}^{+} \mathrm{CD} 64^{-}$cells was seen (both CD64 ${ }^{-} \mathrm{F} 4 /$ $80^{+}$and $\mathrm{CD} 64^{-} \mathrm{F} 4 / 80^{-}$subsets). This further supported that CD64 is useful to distinguish between $\mathrm{CDCs}$ and $\mathrm{M} \phi$ among the nasal $\mathrm{CD} 103^{-} \mathrm{CD}_{11 \mathrm{~b}}{ }^{+}$cells. Immunofluorescent staining of the NALT further confirmed the dramatic increase in CD11 $\mathrm{c}^{+}$ cells seen in the B16-FLT3L mice but not the B16 melanomaimplanted mice (Figure 3c).

In order to further confirm these data, we performed additional experiments comparing the nasal populations of B16 and B16-FLT3L mice using mass cytometry (CyTOF), a novel, potentially paradigm-changing technology that combines the principles of flow cytometry with mass spectrometry, thereby allowing the simultaneous examination of significantly more variables per cell than is possible by conventional flow cytometry. ${ }^{38}$ We analyzed nasal cell suspensions using a 20 parameter CyTOF panel focused on DC- and $\mathrm{M} \phi$-associated markers (Supplementary Table S4). We clustered DNA ${ }^{+}$ $\mathrm{CD} 45^{+}$events into a minimum-spanning tree of phenotypically related nodes using spanning-tree progression analysis of density-normalized events ${ }^{24}$ (Figure 4). Node clusters corresponding to definable cell populations were manually annotated on the basis of canonical marker expression, while preserving visualization of unidentified clusters within the data set. The spanning-tree progression analysis of densitynormalized event trees showed a clear and striking expansion of the CD11c-expressing DC populations following FLT3L treatment (Figure 4a). The expanding populations also expressed high levels of MHCII, and further delineation of the underlying phenotypic heterogeneity revealed a distribution of CD24, CD103, CD117, and CD11b expression among the expanding subsets, whereas there was no expansion in the CD64-expressing populations. For the sake of representation, only FLT3L-treated mice, focusing on putative $\mathrm{CDC}$ and $\mathrm{M} \phi$, are shown in Figure $\mathbf{4 b}$. These data are summarized in Figure $4 \mathbf{c}$, comparing the fold-change differences in the annotated cell populations as a percentage of total $\mathrm{CD} 45^{+}$ cells between the B16-FLT3L and B16 mice. Fold-change differences showed a dramatic expansion in $\mathrm{CD} 24^{\mathrm{hi}} \mathrm{CD} 103^{\mathrm{lo}}$ (73-fold) nasal cells in the B16-FLT3L-treated mice. Notably, these cells were $\mathrm{MHCII}{ }^{\mathrm{hi}} \mathrm{CD} 11 \mathrm{c}^{+} \mathrm{CD} 11 \mathrm{~b}^{+}$, thus confirming the flow cytometry data. In addition, FLT3L treatment resulted in expansion in $\mathrm{CD} 24^{\text {hi }} \mathrm{CD} 103^{\text {hi }}$ cells (40-fold).

Together, these data show that the nasal cDCs include a FLT3L responsive, minor $\mathrm{CD}_{103}{ }^{+}$population and a major $\mathrm{CD}_{11 \mathrm{~b}^{+}}$population that is $\mathrm{CD} 24^{+}$and $\mathrm{CD} 64^{-}$. In addition, within the $\mathrm{CD} 11 \mathrm{~b}^{+}$population, $\mathrm{CD} 64^{+}$cells are FLT3L unresponsive, $M \phi$-like cells. Ontogenic and functional data shown below further confirm these results.

\section{Zbtb46-DTR and Lysm ${ }^{\text {Cre }} \times$ Csf1 ${ }^{\text {LsL - DTR }}$ identify cDC and $M \phi$, respectively, in the nose}

Within the hematopoietic compartment, the zinc finger transcription factor Zbtb46 is specifically expressed by cDC as opposed to the overlapping expression of CD11c on DCs, $\mathrm{M} \phi$, and activated monocytes. ${ }^{39,40}$ Moreover, a recently described $L y s m^{\mathrm{Cre}} \times$ Csfl $1 r^{\mathrm{LsL}-\mathrm{DTR}}\left(\mathrm{MM}^{\mathrm{DTR}}\right)$ mouse model identifies monocytes and $M \phi{ }^{41}$ Using a cell niche depletion approach, we defined $\mathrm{cDC}$ and $\mathrm{M} \phi$ in the nose using $\mathrm{zDC}^{\mathrm{DTR}}-\mathrm{WT}$ (referred to as $\mathrm{zDC}^{\mathrm{DTR}}$ ), Lysm ${ }^{\mathrm{Cre}} \times$ Csfl $^{\mathrm{LsL}-\mathrm{DTR}}$-WT $\left(\mathrm{MM}^{\mathrm{DTR}}\right)$, and WT-WT (WT) bone marrow chimeric mice. Nasal mononuclear cells were examined $24 \mathrm{~h}$ post administration of diphtheria toxin (DT). In the $\mathrm{zDC}^{\mathrm{DTR}}$ mice, among the $\mathrm{CD}_{11 \mathrm{c}^{+}} \mathrm{MHCII}^{+}$gated cells, $\mathrm{CD} 03^{+} \mathrm{CD} 1 \mathrm{~b}^{-}$cells (called $\mathrm{CD}_{103}{ }^{+} \mathrm{DC}$ henceforth) were depleted significantly and $\mathrm{CD} 103^{+} \mathrm{CD} 1 \mathrm{~b}^{+}$cells (called $\mathrm{CD} 103^{+} 11 \mathrm{~b}^{+} \mathrm{DC}$ ) tended to reduce as well. In contrast, in the $\mathrm{MM}^{\mathrm{DTR}}$ mice $\mathrm{CD} 103^{+} \mathrm{DC}$, $\mathrm{CD}_{103}{ }^{+} \mathrm{CD}_{11 \mathrm{~b}}{ }^{+} \mathrm{DC}$ s were not depleted, while the $\mathrm{CD} 103^{-}$ $\mathrm{CD} 1 \mathrm{~b}^{+}$cells were significantly depleted. (Figure 5a,b). On further examining the $\mathrm{CD} 103^{-} \mathrm{CD}^{-11 b^{+}}$cells, we found that in the $\mathrm{zDC}^{\mathrm{DTR}}$ mice $\mathrm{CD} 11 \mathrm{~b}^{+} \mathrm{CD} 64^{-} \mathrm{F} 4 / 80^{-}$cells were significantly depleted, while they were unaffected in the $M M^{\mathrm{DTR}}$ mice, confirming these cells to be cDCs. In addition, the $\mathrm{CD} 11 \mathrm{~b}^{+} \mathrm{CD} 4^{+} \mathrm{F} 4 / 80^{+}$cells and $\mathrm{CD} 11 \mathrm{~b}^{+} \mathrm{CD} 64^{-} \mathrm{F} 4 / 80^{+}$ cells were significantly depleted in the $\mathrm{MM}^{\mathrm{DTR}}$ mice, confirming these cells to be derived from the macrophage/ monocytic lineage. Thus, based on ontogeny, we could define $\mathrm{CD}_{103}{ }^{+} \mathrm{CD} 11 \mathrm{~b}^{-}$and $\mathrm{CD} 11 \mathrm{~b}^{+} \mathrm{CD} 64^{-} \mathrm{F} 4 / 80^{-}$cells as CDC in the nose.

\section{Nasal DCs present soluble antigen to OVA-transgenic $T$ cells and induce MLR to allogeneic T cells}

Having examined the anatomical, phenotypic, morphological, and ontogenetic features of nasal "DCs," we sought to use functional assays to confirm that these cells were indeed bona fide DCs. Antigen presentation to syngeneic T cells and mixed 
a
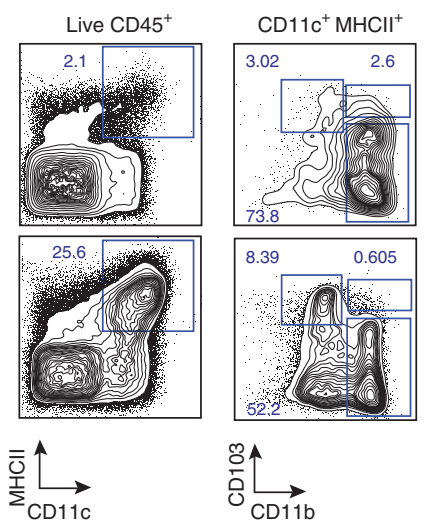

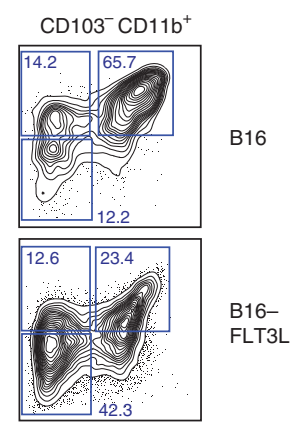

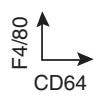

b

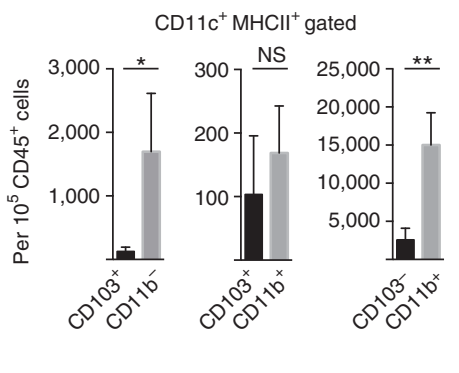

c
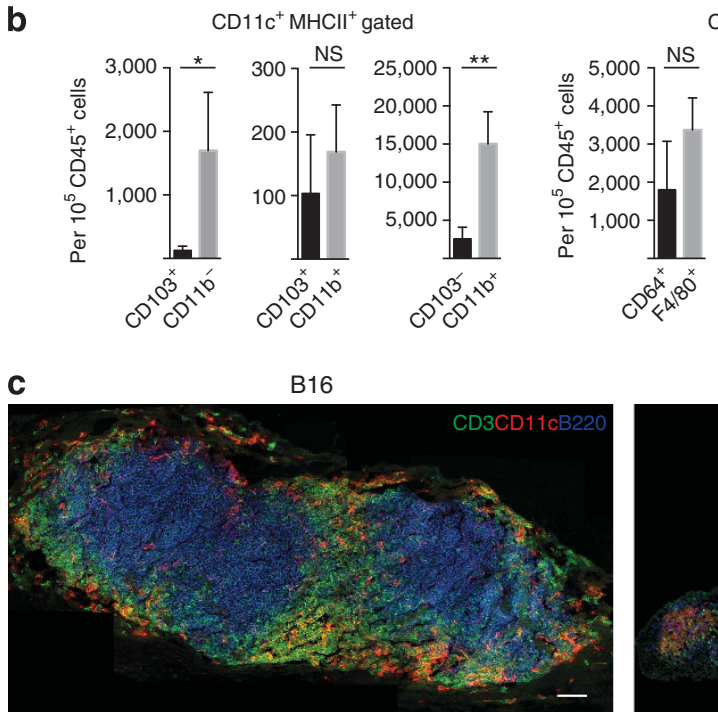

$\mathrm{CD}^{103^{-}} \mathrm{CD}^{11 \mathrm{~b}^{+} \text {gated }}$

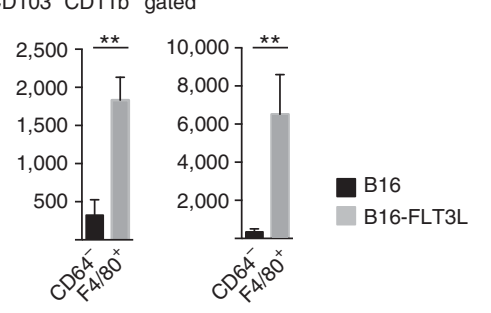

B16-FLT3L

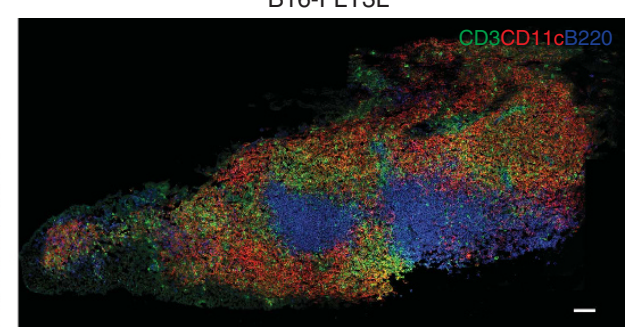

Figure 3 Identification of Fms-related tyrosine kinase 3 ligand (FLT3L) responsive nasal dendritic cell (DC) subsets. C57BL/6 wild-type (WT) mice were implanted with 5-7 $\times 10^{6}$ B16-FLT3 ligand melanoma cells (B16-FLT3L) or B16 melanoma cells (B16), and the nasal DC subsets were analyzed by multiparameter flow cytometry $(\mathbf{a}, \mathbf{b})$ or immunofluorescence $(\mathbf{c})$ after 10-14 days of tumor implantation. (a) Representative flow cytometry panels comparing the expansion of putative nasal DCs in B16 or B16-FLT3L mice. (b) Cumulative data from three individual experiments Error bars $=$ s.d. ${ }^{*} P<0.05,{ }^{*} P<0.01$; ns, not significant. (c) Nasal cryosections from mice implanted with B16-FLT3L or B16 melanoma cells were stained for CD3 (green), CD11c (red), and B220 (blue). Bars $=50 \mu \mathrm{m}$. The entire nasal associated lymphoid tissue (NALT) is depicted here by combining individual images in Adobe Photoshop CC.

leukocyte reaction (MLR) to allogeneic T cells is among the most distinctive characteristics of DCs and distinguishes them from the closely related $\mathrm{M} \phi{ }^{42}$ In order to obtain sufficient numbers of cells to run functional assays and guided by the results of our FLT3L experiments, mice were implanted with B16-FLT3L melanoma cells. Nasal DCs (defined as

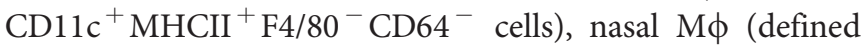
as $\mathrm{CD} 11 \mathrm{c}^{+} \mathrm{MHCII}^{+} \mathrm{F} 4 / 80^{+} \mathrm{CD}^{+} 4^{+}$cells), splenic DCs (defined as Lin $^{-} \mathrm{CD} 11 \mathrm{c}^{\text {hi }} \mathrm{CD} 11 \mathrm{~b}^{\text {int }}$ cells, used as a positive control), and splenic B cells (negative control) were obtained by flow cytometric sorting. Notably, among the $\mathrm{CD}_{11 \mathrm{c}^{+}} \mathrm{MHCII}^{+}$cells, the $\mathrm{CD} 103^{+}$and $\mathrm{CD}_{11 \mathrm{~b}}{ }^{+}$subsets could not be used for co-cultures separately due to cell number limitations.

For the antigen-presentation assays, respective cell populations were co-cultured with carboxyfluorescein succinimidyl ester (CFSE)-labeled ovalbumin (OVA)-transgenic (OT-II)
$\mathrm{CD} 4{ }^{+} \mathrm{T}$ cells in the presence OVA. To exclude the possibility that the OVA protein was degraded into peptides, which then bound spontaneously to MHCII molecules on $\mathrm{T}$ cells and induced T-cell proliferation, we also included a control wherein OT-II cells were cultured in the presence of OVA alone, without DCs. The frequency of proliferating, $\mathrm{V} \alpha 2{ }^{+} \mathrm{CD} 4{ }^{+} \mathrm{CFSE}^{\text {lo }}$ $\mathrm{T}$ cells was quantified after 5 days of culture. A clear difference in antigen-presenting ability was noted between nasal DCs and $M \phi$. Although nasal DCs, analogous to splenic DCs induced OT-II proliferation in the presence of OVA, nasal $\mathrm{M} \phi$ analogous to splenic B cells did not (Figures 6a,b). OT-II cells cultured in the presence of OVA alone did not proliferate (data not shown). Nasal DCs showed poor ability to crosspresent to $\mathrm{CD} 8{ }^{+} \mathrm{T}$ cells. This probably reflects the distribution of DCs in the nose, i.e., cross-presenting, CD8-priming, $\mathrm{CD}_{103}{ }^{+}$DCs are a minority population, whereas the CD4priming $\mathrm{CD} 11 \mathrm{~b}^{+}$DCs are the dominant population. 
a

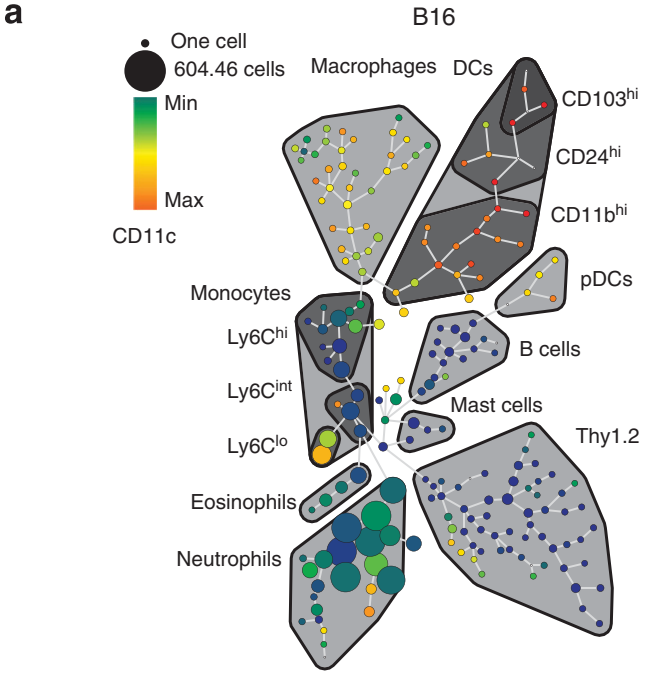

B16-FLT3L

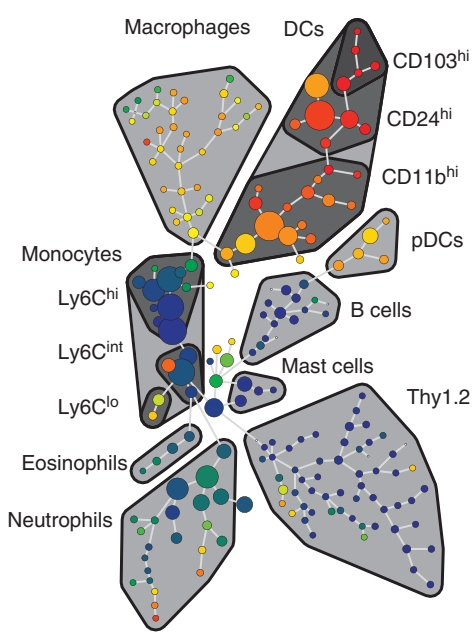

b
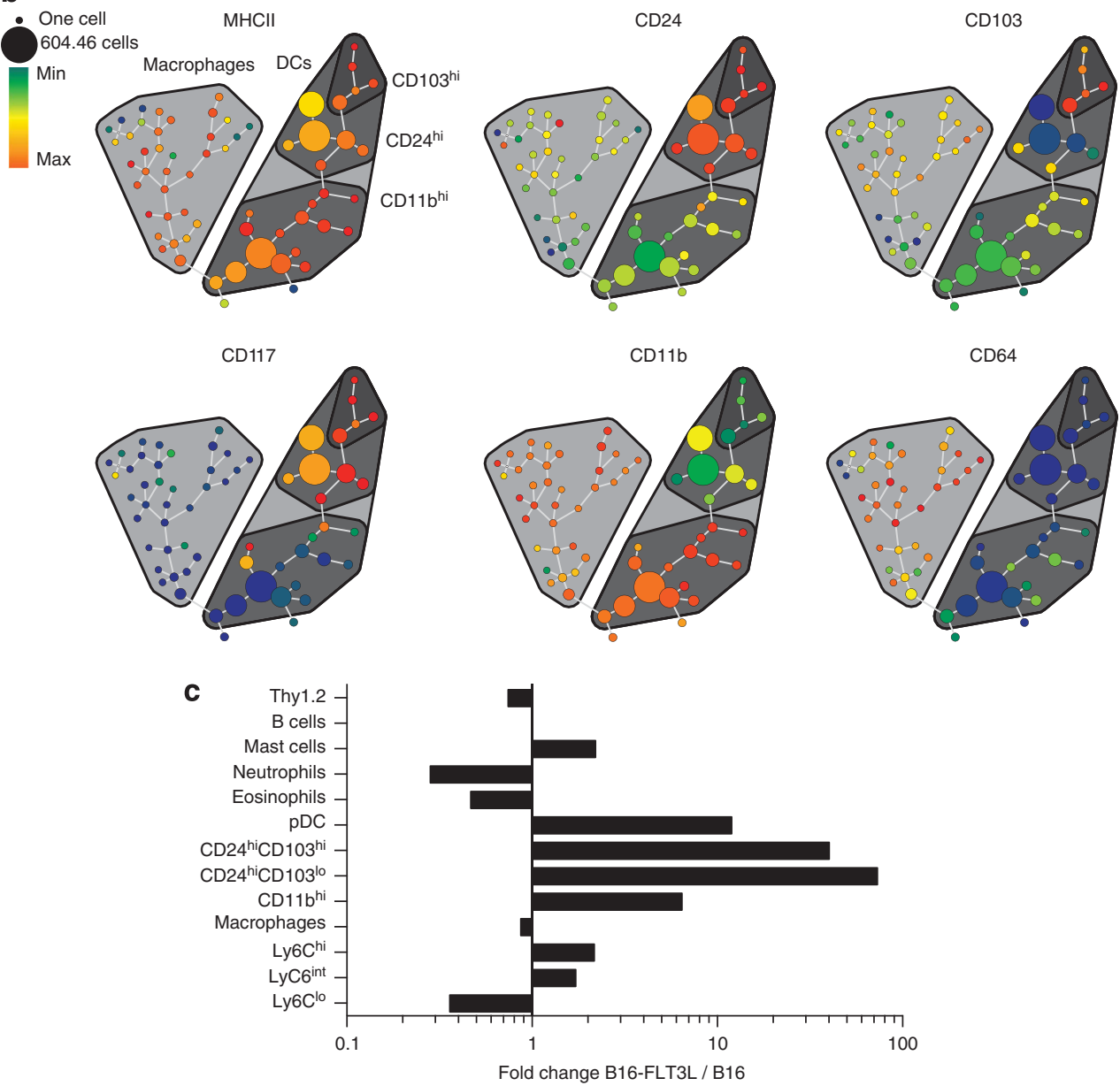

Figure 4 CYTOF plots comparing nasal populations in B16 melanoma and Fms-related tyrosine kinase 3 ligand (FLT3L)-B16 melanoma mice. (a) Spanning-tree progression analysis of density-normalized event (SPADE) plots showing the expression of CD11c in nasal mononuclear cell populations as indicated. (b) Macrophage and dendritic cell (DC) focused on spade trees showing the expression of the indicated markers in FLT3L-treated mice. The size of each node represents the number of cells, and the strength of expression of the respective marker is indicated by the color as specified in the legend. (c) Summary of the CYTOF data showing fold changes in the respective populations, comparing nasal populations in B16 and B16-FLT3L mice.

For MLR assays, the nasal DCs, nasal M $\phi$, splenic DCs, and splenic B cells were cultured with CFSE-labeled BALB/c splenic $\mathrm{T}$ cells (as the allogeneic responders). Nasal DCs effectively stimulated allogeneic T cells similar to splenic DCs, while nasal $\mathrm{M} \phi$ and splenic B cells were poor at inducing MLR (Figures 6a,b). These data highlight the functional differences 
a

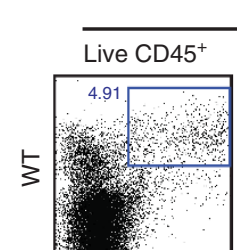

Nose
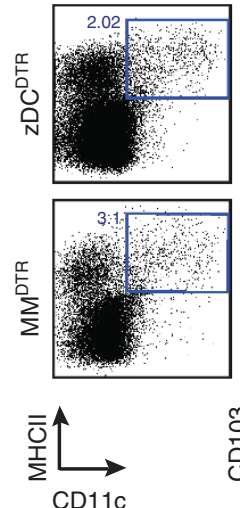

b

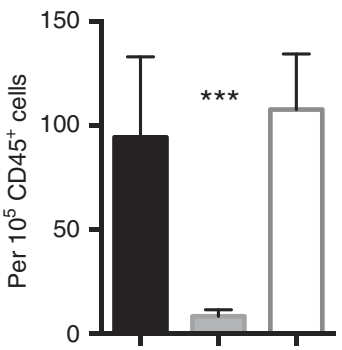

$\mathrm{CD}_{103}{ }^{+} \mathrm{CD} 11 \mathrm{~b}$

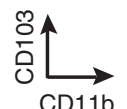

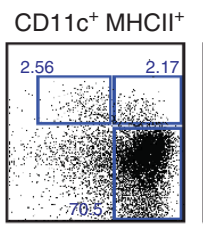
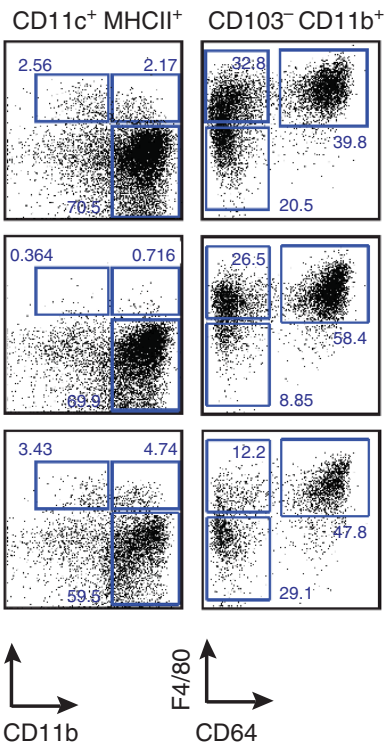

$\mathrm{MHClI}^{+} \mathrm{CD} 11 \mathrm{c}^{+}$gated

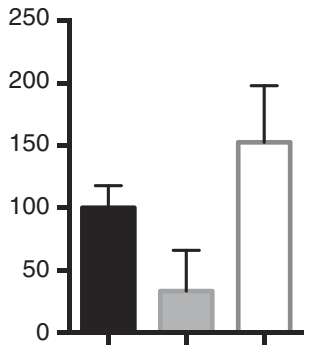

$\mathrm{CD}_{103}{ }^{+} \mathrm{CD} 11 \mathrm{~b}^{+}$

CD103-CD11b+ gated
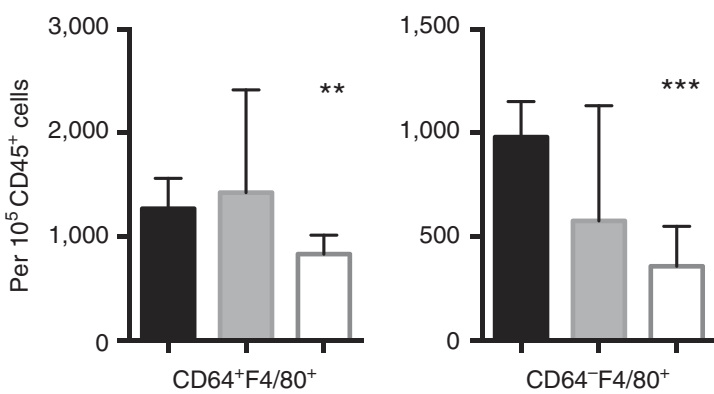
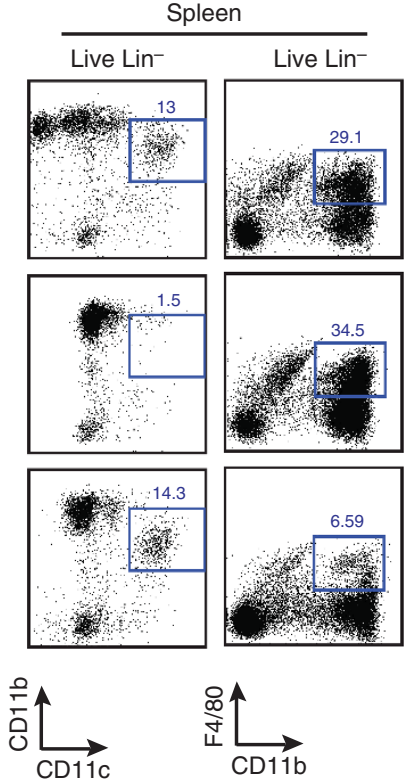

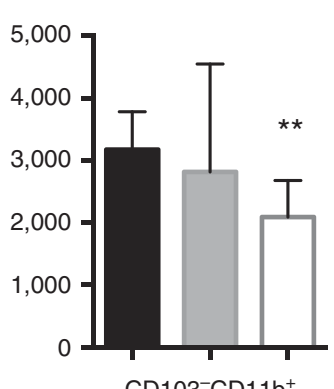

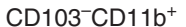

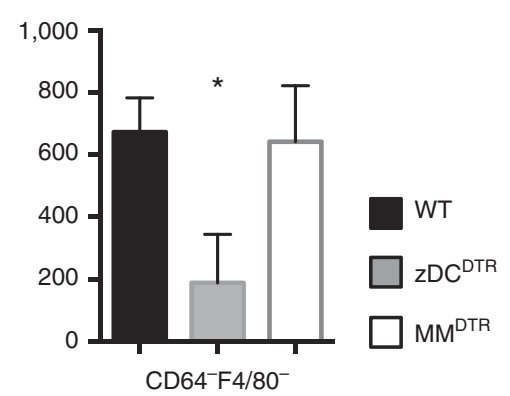

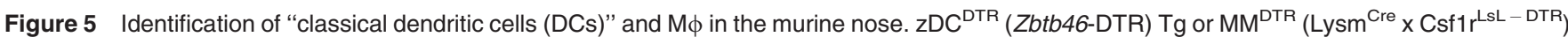
or wild-type (WT) bone marrow chimeric mice were injected intraperitoneally (i.p.) with 500 ng diphtheria toxin (DT) and live, CD45 ${ }^{+}$nasal cells were analyzed for expression of CD11c, MHCII, CD103, CD11b, F4/80, and CD64 1-day post DT administration. Numbers represent the percentage of cells in the indicated gate. (a) Representative flow cytometry plots comparing the percentage of nasal antigen presenting cells between WT, zDC ${ }^{\mathrm{DTR}}$ and $\mathrm{MM}^{\mathrm{DTR}}$ mice. (b) Cumulative data from three individual experiments is depicted here. Error bars $=\mathrm{s} . \mathrm{d}$. ${ }^{\star} P<0.05,{ }^{\star \star} P<0.01,{ }^{\star \star \star} P<0.001$.

between $\mathrm{CD} 11 \mathrm{c}^{+} \mathrm{MHCII}^{+} \mathrm{F} 4 / 80^{-} \mathrm{CD}^{-} 4^{-}$cells and $\mathrm{CD} 11 \mathrm{c}^{+}$ $\mathrm{MHCII}^{+} \mathrm{F} 4 / 80^{+} \mathrm{CD}^{+} 4^{+}$cells, and confirm the former to be bona fide DCs within the nose.

\section{Nasal DCs migrate in response to LPS}

Migratory behavior is a hallmark of DCs. ${ }^{43}$ To investigate this as yet another criteria to define nasal DCs, mice were administered OVA-Alexa 488 in combination with LPS delivered intranasally. The nose and draining lymph nodes (LNs) were examined at serial time points $(1,6,12$, and $24 \mathrm{~h}$ post administration). Phosphate-buffered saline (PBS)-administered mice were used as controls at each time point. In the nose, we assessed the uptake of OVA by live, $\mathrm{CD} 45^{+}$cells and found that a minority $(\sim 3 \%)$ of $\mathrm{OVA}^{+}$nasal cells were $\mathrm{CD}_{11 \mathrm{c}^{+}} \mathrm{MHCII}^{+}$, with peak labeling seen at $6 \mathrm{~h}$ and declining by $24 \mathrm{~h}$. Further examination of the $\mathrm{OVA}^{+} \mathrm{CD} 1 \mathrm{c}^{+} \mathrm{MHCII}^{+}$ 


\section{a}

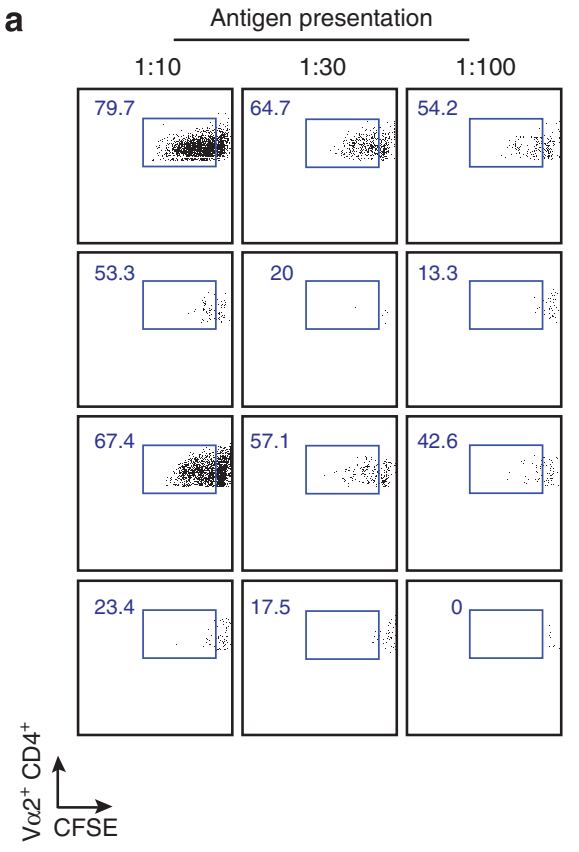

b

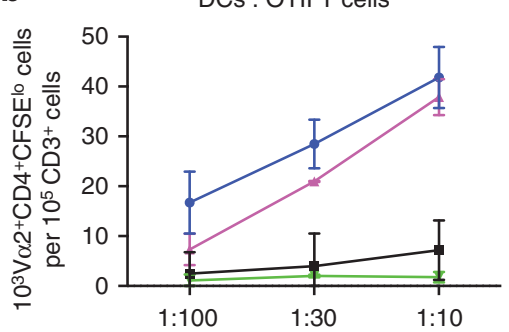

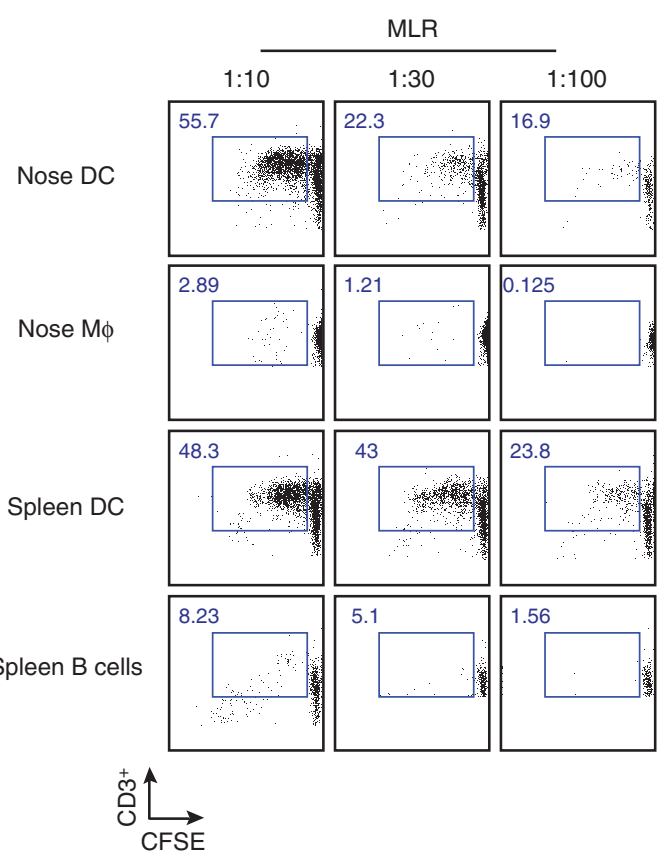

C57 Bl/6 DCs: Balb/c T cells

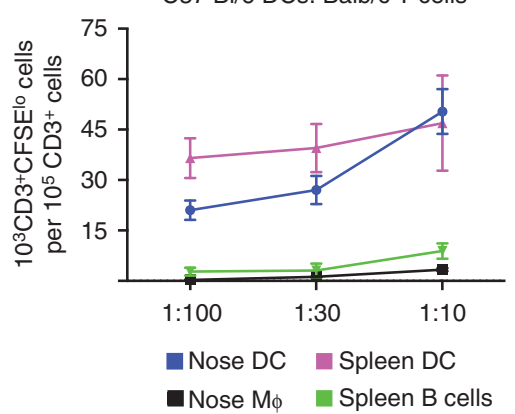

Figure 6 Nasal dendritic cells (DCs) present antigen to $\mathrm{CD}^{+}{ }^{+} \mathrm{T}$ cells and induce proliferation of allogeneic $\mathrm{T}$ cells in a mixed leukocyte reaction (MLR). (a) Nasal DCs from C57BL/6 mice were expanded with B16-FLT3L cells for 10-14 days before sorting. Nasal antigen presenting cells were sorted into two subsets: $\mathrm{CD} 11 \mathrm{C}^{+} \mathrm{MHClI}^{+} \mathrm{F} 4 / 80^{-} \mathrm{CD}^{-} 4^{-}$cells indicated as nose DCs and $\mathrm{CD} 11 \mathrm{C}^{+} \mathrm{MHClI}^{+} \mathrm{F} 4 / 80^{+} \mathrm{CD} 64^{+}$cells indicated as nose M $\phi$. Sorted cells were cultured in the indicated DC:T-cell ratio for 5 days with carboxyfluorescein succinimidyl ester (CFSE)-labeled splenic OT-II cells (left) or BALB/c splenic T cells (right). Spleen DCs were used as the positive control and spleen B cells were used as the negative control. Representative flow cytometry plots comparing the proliferation of $\mathrm{V} \alpha 2^{+} \mathrm{CD} 4{ }^{+} \mathrm{T}$ cells (left) or allogeneic $\mathrm{T}$ cells (right) by nasal $\mathrm{DCs}$ and $\mathrm{M} \phi$. Cumulative data from one of three experiments is shown here. Error bars $=\mathrm{s.d}$. (b) Quantification of the number of proliferated $\left(\mathrm{CFSE}{ }^{\mathrm{lo}}\right.$ ) OT-II T cells (left) or Balb/c T cells (right). Cumulative data from one of three experiments is shown here. Error bars $=s . d$.

cells revealed them to be predominantly $\mathrm{CD}_{11} \mathrm{~b}^{+}(\sim 99 \%)$. Among the $\mathrm{CD}_{11 \mathrm{~b}^{+}}$cells, $\sim 80 \%$ of $\mathrm{OVA}^{+}$cells were $\mathrm{CD} 64^{-}$ bona fide DCs. Interestingly, a majority of the total $\mathrm{OVA}^{+}$ nasal cells were $\mathrm{CD}_{11 \mathrm{c}^{-}} \mathrm{MHCII}^{\mathrm{lo} / \mathrm{int}} \mathrm{ly} 6 \mathrm{C}^{\mathrm{hi}}$ ly6G $\mathrm{G}^{\mathrm{hi}} \mathrm{SSC}^{\mathrm{int}}$ granulocytes. Peak uptake of OVA by granulocytes occurred at $6 \mathrm{~h}$ and declined over $24 \mathrm{~h}$ (although persisting well above baseline at $24 \mathrm{~h}$ ). In addition, a small population of $\mathrm{OVA}^{+} \mathrm{CD} 11 \mathrm{c}^{-}$ $\mathrm{MHCII}^{\mathrm{lo} / \text { int }} \mathrm{ly} 6 \mathrm{C}^{\mathrm{hi}} \mathrm{ly} 6 \mathrm{G}^{-} \mathrm{SSC}^{\mathrm{lo}}$ monocytes appeared at $6 \mathrm{~h}$ and persisted over $24 \mathrm{~h}$ in the nose (Figures $7 \mathbf{a}, \mathbf{b}$ ).

In parallel to the nose assessments, we also examined the draining LNs-both cervical LN (cLN) and mediastinal LN for migratory DCs (live, $\mathrm{OVA}^{+} \mathrm{lin}^{-} \mathrm{MHCII}{ }^{\mathrm{hi}} \mathrm{CD} 11 \mathrm{c}^{+}$cells). As shown in Figure $7 \mathbf{a}$ and quantified in Figure $7 \mathbf{b}$, a small population of $\mathrm{OVA}^{+}$migratory DCs could be detected in the cLN at $6 \mathrm{~h}$, with a progressive and striking increase at $24 \mathrm{~h}$. Further analyses of these migratory DCs within the cLN revealed them to be predominantly $\mathrm{CD} 11 \mathrm{~b}^{+} \mathrm{CD}^{-} 4^{-}$, with a small number of $\mathrm{CD} 103^{+} \mathrm{CD}_{11 b^{-}}$and $\mathrm{CD} 103{ }^{+} \mathrm{CD} 11 \mathrm{~b}^{+}$ DCs as well, reflecting the numeric distribution of these DC subsets in the nose. As much as $40 \%$ of the OVA + cells in the cLN at $24 \mathrm{~h}$ were CD11c $\mathrm{c}^{\mathrm{int} /}-\mathrm{MHC}-\mathrm{II}^{\text {int/lo }}$ (Figure $7 \mathbf{a}$ ). However, we did not include granulocyte-specific markers in the LN panel. Therefore, we were unable to confirm whether $\mathrm{OVA}^{+}$neutrophils also migrate into the LN. Interestingly, we did not detect $\mathrm{OVA}^{+}$migratory DCs within the mediastinal $\mathrm{LN}$ even at $24 \mathrm{~h}$ (data not shown). Thus, we were able to demonstrate clear uptake of a fluorescent antigen by nasal DCs and their subsequent migration to the draining LN.

Next, to examine the response of nasal DCs to Gramnegative pathogens, Salmonella enterica serovar Typhimurium constitutively expressing mCherry (Salmonella-mCherry) was administered intranasally to CD11c-eYFP transgenic mice. To 


\section{ARTICLES}

compare DC-associated or DC-independent clearance of Salmonella from the nose, we co-administered either PBS or pertussis toxin (PTX). The latter is a known inhibitor of
DC motility. ${ }^{34}$ Using two-photon microscopy, SalmonellamCherry were seen in the nasal cavity as early as $5 \mathrm{~min}$ after application, distributed within the nasal lumen (Figure 7d) as
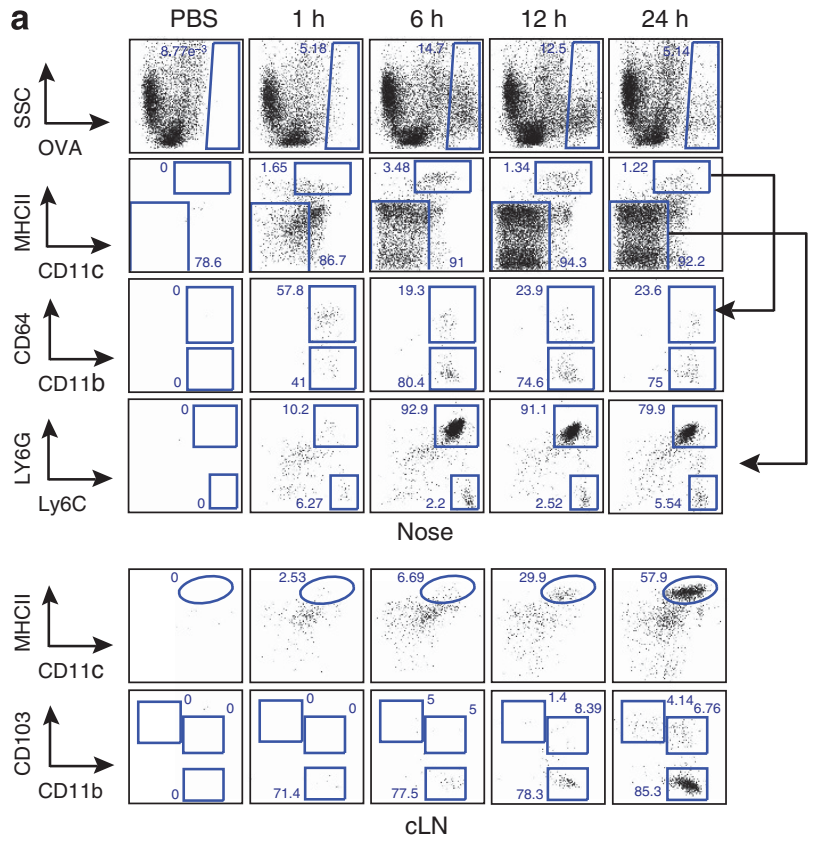

C

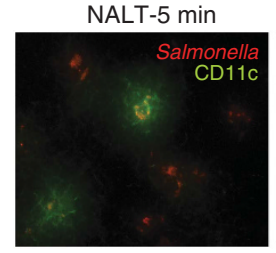

d
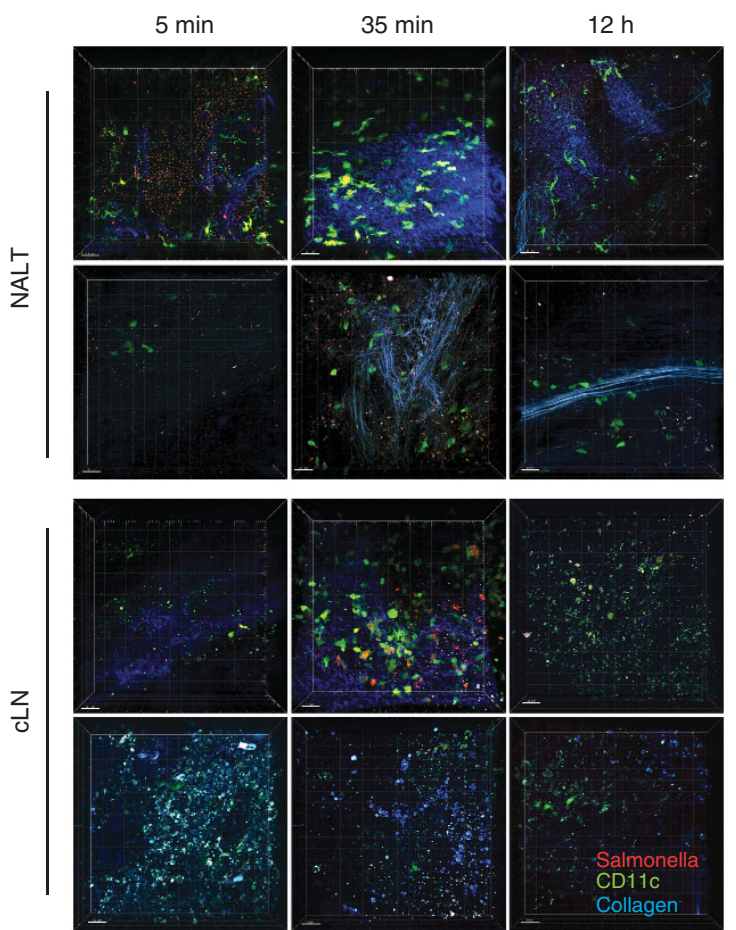

b

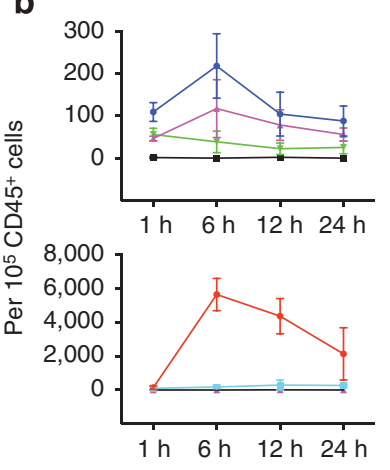

OVA ${ }^{+} \mathrm{CD} 11 \mathrm{c}^{+} \mathrm{MHCII}$

OVA $^{+}$CD11 ${ }^{+} \mathrm{MHCII}^{\mathrm{hi}} \mathrm{CD} 11 \mathrm{~b}^{+} \mathrm{CD} 64$

OVA $^{+} \mathrm{CD} 11 \mathrm{c}^{+} \mathrm{MHCII}^{\mathrm{hi}} \mathrm{CD} 11 \mathrm{~b}^{+} \mathrm{CD} 64^{+}$

OVA ${ }^{+} \mathrm{CD} 11 \mathrm{c}^{-} \mathrm{MHCII}^{-} \mathrm{CD} 11 \mathrm{~b}^{+}$Ly6C $\mathrm{C}^{\text {hi }} \mathrm{Ly} \mathrm{GG}^{+}$

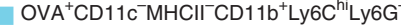
- PBS

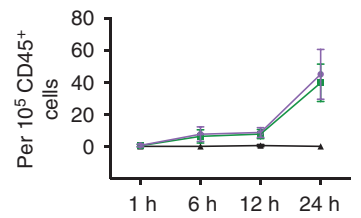

OVA ${ }^{+} \mathrm{CD} 11 \mathrm{C}^{+} \mathrm{MHCI}{ }^{\mathrm{hi}}$

OVA ${ }^{+} \mathrm{CD} 11 \mathrm{c}^{+} \mathrm{MHCII}{ }^{\mathrm{hi}} \mathrm{CD} 11 \mathrm{~b}^{+} \mathrm{CD} 103$

PBS
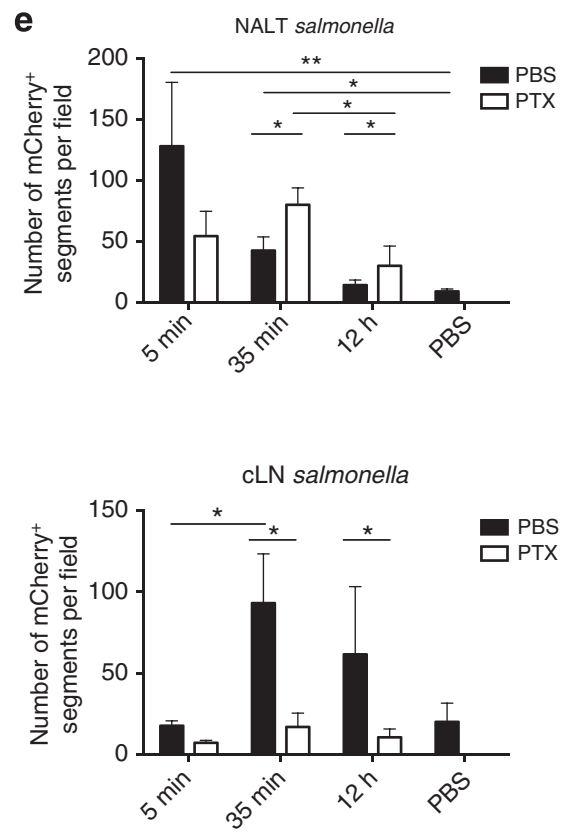
well as occasionally internalized within $\mathrm{CD}_{11 \mathrm{c}^{+}}$nasal cells (Figure $7 \mathrm{c}$ ). With surprising kinetics, $35 \mathrm{~min}$ post administration, in the PBS group, a $(\sim 50 \%)$ decline in mCherry $^{+}$cells was seen in the nose. In contrast, PTX-treated mice had a significantly greater number of mCherry ${ }^{+}$cells compared with the nose of PBS-treated mice. This difference persisted at $12 \mathrm{~h}$ (Figures $7 d, e)$. Analogously, within the cLN, a striking increase in mCherry ${ }^{+}$cells was seen in the PBS-treated but not PTXtreated mice at $35 \mathrm{~min}$ and $12 \mathrm{~h}$. These data demonstrate a rapid flux of Salmonella into the draining LNs and highlights the rapid response of the antigen-presenting cells in the nose to a bacterial challenge, which is attenuated by PTX, an inhibitor of DC migration.

\section{BDCA-1 ${ }^{+}$DCs form the predominant DC population in human nasopharyngeal tissue at steady state and are significantly reduced during chronic inflammation}

To identify nasal DCs in humans, we analyzed nasopharyngeal and sinus tissues from 10 normal volunteers (a total of 10 tissue samples) and 10 patients with CRS (a total of 21 tissue samples; Supplementary Table S1). The CRS patients were further divided into patients with and without nasal polyps, as these two clinical entities show distinct phenotypes, with patients having nasal polyps being more refractory to treatment. The clinical parameters that were assessed included patient age, sex, tissue analyzed, indications for surgery, and a thorough list of the concomitant medications immediately proximal to the surgery. The mean age of normal volunteers was 52 years (range 25-82), the mean age of patients with CRS was 52 years (range 40-75), while the mean age of patients with CRS/nasal polyps was 50 years (range 33-61). Patients with CRS demonstrated greater use of steroids and antibiotics. We performed a detailed multicolor flow cytometric analysis, first gating on single cells, live cells, $\mathrm{CD} 45^{+}$, and lymphocyte lineage-negative BDCA- ${ }^{+}$ cells, and we also surface labeled for BDCA $-2^{+}$and BDCA- $3^{+}$. Three distinct populations of human nasal DCs were identified as BDCA- ${ }^{+}$myeloid DCs, BDCA-2 ${ }^{+}$plasmacytoid DCs, and BDCA- $3^{\text {hi }}$ myeloid DCs (Figure 8a). We observed a significantly higher frequency of BDCA-1 ${ }^{+}$DCs rather than BDCA $-3^{\text {hi }}$ DCs in normal volunteers as well as in patients with CRS. More importantly, when compared with normal volunteers, patients with CRS displayed a significantly lower frequency of BDCA-1 ${ }^{+}$DCs $(P<0.05)$ and a trend toward lower BDCA- $3^{\text {hi }}$ DCs $(P=0.07)$. These differences were not seen on comparing normal volunteers and patient with CRS with nasal polyps (Figure 8b). In addition to the DC subsets described above, a detailed analysis of nasal mononuclear cells was performed. This included monocyte subsets, neutrophils, $\mathrm{T}$ cells, $\mathrm{B}$ cells, and NK cells. A decline in the BDCA- ${ }^{+}$and BDCA $-3^{\text {hi }}$ DCs was not accompanied by a corresponding increase in other inflammatory cells within the nose (Supplementary Figure S3).

\section{DISCUSSION}

Mucosal vaccination is considered to be superior to systemic vaccines for the generation of local and perhaps disseminated mucosal immune responses. Owing to its non-invasive nature and imminent antigen availability (most notably circumventing enzymatic degradation that precedes gastrointestinal mucosal absorption), i.n. antigen delivery appears to be the most feasible and clinically relevant of the various routes of mucosal vaccination and is supported by the rapid development of newer technologies to improve vaccine potency (chitosan derivatives) ${ }^{44}$ and safety (nanogels). ${ }^{45}$ In fact, a substantial research initiative funded by the Bill and Melinda Gates foundation focuses on the development of novel, needlefree mucosal vaccines. ${ }^{37}$ In spite of these advances, basic descriptions of DCs in the nasal mucosa are lacking.

The observation that nasally delivered vaccines can induce antigen-specific immunity across a wide variety of systemic and mucosal sites ${ }^{21}$ led us to hypothesize that the nasal tissue would contain a high density of DCs. In support of our hypothesis, we observed that a robust population of DCs patrols the nasal cavity, anatomically distributed in sub-epithelial, peri-vascular, and peri-lymphatic spaces, poised to respond to antigen. The latter was confirmed by the rapid kinetics of nasal DC mobilization following i.n. administration of LPS or pathogenic Gram-negative bacteria. Further, we observed nasal DCs to possess a high phenotypic diversity with distinct subsets contained within $\mathrm{CD}_{11 \mathrm{c}^{+}} \mathrm{MHCII}^{+}$cells. Specifically, $\mathrm{CD}_{11 \mathrm{c}^{+}} \mathrm{MHCII}^{+}$gated $\mathrm{CD} 103^{+} \mathrm{CD} 1 \mathrm{~b}^{-}$nasal cells and $\mathrm{CD} 11 \mathrm{~b}^{+} \mathrm{CD} 64^{-} \mathrm{F} 4 / 80^{-}$nasal cells are dependent on the transcription factor $z b t b 46$ and show a preferential expansion by the cytokine FLT3L, defining these cells as "classical DCs," capable of inducing a mixed leucocyte reaction and antigen presentation. In addition, these cells demonstrate classical DC morphology ${ }^{43}$ and migrate in response to antigen. In contrast to the DCs, $\mathrm{CD} 11 \mathrm{~b}^{+} \mathrm{CD} 64^{+} \mathrm{F} 4 / 80^{+}$cells in the nose did not

Figure 7 Migration of nasal dendritic cells (DCs) to cervical draining lymph nodes (LNs). (a,b) Targeting of nasal DCs and neutrophils following intranasal administration of OVA-Alexa 488 and migration of OVA ${ }^{+}$DCs to the cervical LNs (cLNs). (a,b) At least three wild-type (WT) mice per time point were administered either OVA Alexa 488 plus lipopolysaccharide (LPS) or were given phosphate-buffered saline (PBS) intranasally and analyzed at 1, 6, 12, and $24 \mathrm{~h}$. (a, top) Representative flow cytometric analysis of OVA ${ }^{+}$cells. Both nasal DCs $\left(\mathrm{CD} 11 \mathrm{c}^{+} \mathrm{MHCll}^{+} \mathrm{CD} 11 \mathrm{~b}^{+} \mathrm{CD} 64\right.$

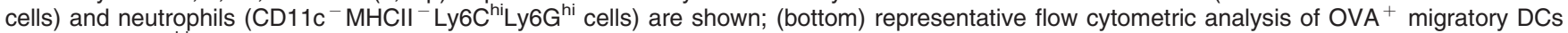
$\left(\mathrm{CD} 11 \mathrm{c}^{+} \mathrm{MHCII}^{\mathrm{hi}}\right.$ cells) in the $\mathrm{CLN}$ at respective time points. (b) Cumulative data from three individual experiments is quantified here. Error bars $=\mathrm{s}$.d. (c) Uptake of $S$. typhimurium by CD11c-eYFP. cells derived from the murine nose and cervical LN is compared. (d) Three-dimensional reconstruction from two-photon microscopy data showed dramatic change in spatial distribution of CD11c-eYFP ${ }^{+}$DCs (green) and mCherry-expressing Salmonella (red) between nasal associated lymphoid tissue (NALT) and cLNs. PBS and pertussis toxin (PTX)-administered mice are compared at 5 min, 35 min, and $12 \mathrm{~h}$ using two-photon microscopy. Second-harmonics signals from collagen are in blue. Bars $=30 \mu \mathrm{m}$. (e) Numbers of mCherry ${ }^{+}$cells in NALT (top) and $\mathrm{cLN}$ (bottom) were quantified using the Imaris software (Bitplane). Each figure is representative of at least three experiments. Error bars =s.d.; original magnification $=\times 400$. 
a
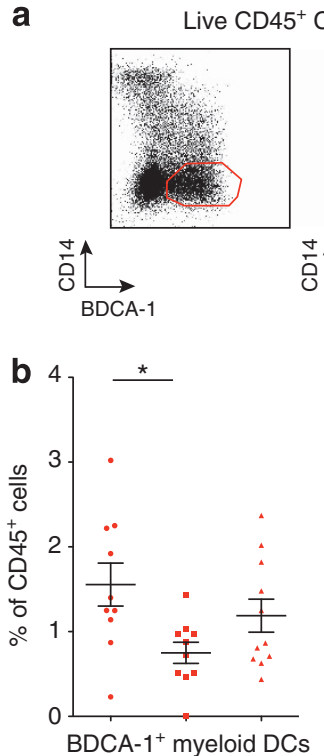

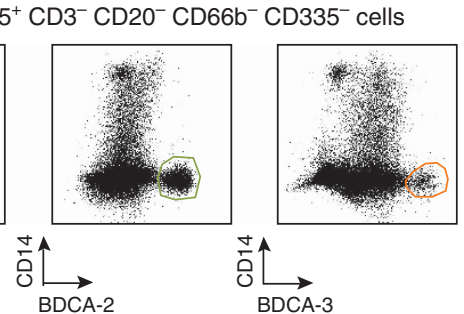

- BDCA-1+ myeloid DCs

- BDCA-2 ${ }^{+}$plasmacytoid DCs

- BDCA-3 $3^{\text {high }}$ myeloid DCs
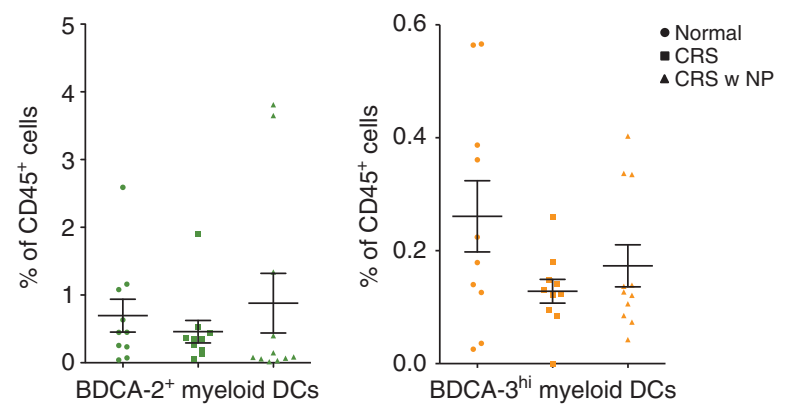

Figure 8 Identification of dendritic cells (DCs) in human nasal mucosa. (a) Live CD45 ${ }^{+}$mononuclear CD3 ${ }^{-} \mathrm{CD}_{20}{ }^{-} \mathrm{CD}_{335^{-}} \mathrm{CD} 6 \mathrm{~b}{ }^{-} \mathrm{CD} 14^{-} \mathrm{cell}^{-}$, i.e., T-, B-, NK-, neutrophils-, and monocyte-excluded cells were analyzed for BDCA-1, -2 , and -3 markers. Three DC populations are shown: BDCA-1 ${ }^{+}$ myeloid DCs (left), BDCA-2 ${ }^{+}$plasmacytoid DCs (middle), and BDCA-3 ${ }^{\text {hi }}$ myeloid DCs (right). (b) Frequency of BDCA $-1^{+}$cells, BDCA-2 ${ }^{+}$cells, and BDCA $-3^{\text {hi }}$ cells as a percent of $\mathrm{CD} 45^{+}$mononuclear cells of normal, chronic rhinosinusitis (CRS), or CRS with nasal polys. Composite data from 20 donors are shown. ${ }^{*} P<0.05$.

expand with FLT3L or deplete with DT in the zbtb46-DTR mice. However, this population was significantly depleted in the $\mathrm{MM}^{\mathrm{DTR}}$ mice. Morphologically, these cells demonstrated a vacuolated cytoplasm with an eccentric, reniform nucleus. Functionally, the $\mathrm{CD} 11 \mathrm{~b}^{+} \mathrm{CD} 64^{+} \mathrm{F} 4 / 80^{+}$cells neither presented antigen nor induced MLR. Based on these criteria, we confirm nasal $\mathrm{CD} 11 \mathrm{~b}^{+} \mathrm{CD} 64^{+} \mathrm{F} 4 / 80^{+}$cells to be $\mathrm{M} \phi$. Moreover, a third population among the $\mathrm{CD} 11 \mathrm{~b}^{+}$cells was seen $-\mathrm{CD} 11 \mathrm{~b}^{+} \mathrm{CD} 64^{-} \mathrm{F} 4 / 80^{+}$. Morphologically, this was a mixed population comprising both DCs (minority of the cells) and $\mathrm{M} \phi$ (majority of the cells). Accordingly, this population is FLT3L responsive on one hand, while being significantly depleted in the $\mathrm{MM}^{\mathrm{DTR}}$ mice on the other. Furthermore, although the $\mathrm{CD} 11 \mathrm{~b}^{+} \mathrm{CD} 64^{-} \mathrm{F} 4 / 80^{+}$cells are also depleted in the $\mathrm{zDC}^{\mathrm{DTR}}$ mice, likely due to the lower number of DCs contained within this heterogeneous subset, the depletion does not meet statistical thresholds. Unexpectedly, the murine nose also contains $\mathrm{CD}_{103}{ }^{+} \mathrm{CD} 11 \mathrm{~b}^{+}$DCs, particularly in the nonNALT nasal tissue that co-express CD11b and CD103 similar to the intestinal lamina propria DC subsets ${ }^{46}$ and are partially $z b t b 46$ dependent (perhaps reflecting their heterogeneous composition). Owing to the small number of these cells, we are unable to perform functional assays specific to this population. However, nasal $\mathrm{CD} 103^{+} \mathrm{CD} 11 \mathrm{~b}^{+}$cells share phenotypic characteristics of CD103 and CD11b DCs; they co-express CD24, CD206, and EpCAM, and appear to be intermediate for $\mathrm{F} 4 / 80$ and $\mathrm{CD} 14$, and thus share characteristics of both $\mathrm{CD} 103^{+}$DCs and CD11b ${ }^{+}$DCs. Thus, we have identified five subsets of antigen presenting cells within the murine nose. $\mathrm{CD} 103^{+} \mathrm{CD}_{11 \mathrm{~b}}{ }^{-}, \mathrm{CD}_{103}{ }^{+} \mathrm{CD} 11 \mathrm{~b}{ }^{+}$, and $\mathrm{CD} 11 \mathrm{~b}^{+} \mathrm{CD} 4^{-} \mathrm{F} 4 / 80^{-}$cells identified as $\mathrm{cDCs}, \mathrm{CD} 11 \mathrm{~b}^{+}$
$\mathrm{CD} 64^{+} \mathrm{F} 4 / 80^{+}$cells identified as $\mathrm{M} \phi$, and $\mathrm{CD} 11 \mathrm{~b}^{+} \mathrm{CD} 64^{-}$ $\mathrm{F} 4 / 80^{+}$cells being a mixed population, comprising both $\mathrm{CDCs}$ and $\mathrm{M} \phi$.

We also document BDCA- ${ }^{+}$and BDCA $3^{\text {hi }}$ myeloid DCs, as well as BDCA- $^{+}$plasmacytoid DCs within the human nasopharyngeal tissue, and observe a decline in myeloid DCs to be associated with CRS. In light of these observations, we believe the present study to be the first comprehensive anatomic, phenotypic, ontogenic, and functional assessments of nasal DCs.

In addition to identifying distinct subsets of myeloid nasal DCs, we conclude that the $\mathrm{CD} 11 \mathrm{~b}^{+} \mathrm{CD} 64^{-} \mathrm{F} 4 / 80^{-}$DCs comprise majority of nasal DCs. In contrast to the Peyer's patches (considered as immune inductive sites for the intestines), which have a high frequency of $\mathrm{CD}_{103}{ }^{+} \mathrm{DCs}$, the NALT (considered as inductive immune sites for the respiratory tract) contains a low frequency of $\mathrm{CD}_{103}{ }^{+}$DCs. The nasal $\mathrm{CD}_{103}{ }^{+}$DCs are langerin ${ }^{+} \mathrm{CD} 24^{+} \mathrm{EpCAM}^{+}$ TLR $^{+}, z b t b 46$ dependent and FLT3L responsive. Therefore, it would appear that the nasal cDCs are responsive to FLT3L, explaining and emphasizing the adjuvant role of FLT3L in nasally delivered vaccines. ${ }^{29,33,36,47}$

To define the anatomic relationships of nasal DCs with other cells, we have used two- and three-dimensional imaging. Twodimensional micrographs suggested a sub-epithelial location of nasal DCs, both within and extraneous to the NALT, in agreement with similar such observations. ${ }^{30}$ Further, a dense network of CD11 chi cells, with a classical "dendritic" morphology was found by two-photon microscopy of the NALT with second harmonics, suggesting a lumen-oriented distribution of nasal DCs. In fact, we documented the extension of dendrites across the NALT epithelium, suggesting that nasal 
DCs sample the luminal contents across intact epithelium akin to the gut resident CX3CR $1^{+}$cells. ${ }^{25}$ In addition, we found nasal DCs to cluster around blood vessels and especially around the lymphatic channels, situated in the posterior aspects of the NALT, and speculate that in the absence of afferent lymphatics perivascular DCs are entering the NALT, while peri-lymphatic DCs are exiting it. Deeper areas within the NALT contained $\mathrm{CD}_{11 \mathrm{c}^{+}}$cells, albeit with a compact, rounded (as opposed to dendritic) appearance on two-photon imaging, perhaps suggesting that as the DCs contacted antigen, they became activated, lost their dendrites, and migrated deeper within the nasal tissue.

As further evidence of function, we tested for DC migration by two sets of studies. In the first, fluorescent OVA was tracked in the nasal tissues as well as draining LNs over time. A majority of the $\mathrm{OVA}^{+}$nasal DCs $(\sim 99 \%)$ were $\mathrm{CD} 103^{-} \mathrm{CD}^{-} 1 \mathrm{~b}^{+}$ $\mathrm{CD}^{-} 4^{-}$that appeared within the CLN by $6 \mathrm{~h}$ and progressively increased over 12-24 h. The kinetics of response to SalmonellamCherry were, however, much different. Within $5 \mathrm{~min}$ of application, although a majority of the bacteria were in the nasal lumen, we could also detect Salmonellae intracellularly within the nasal CD11 ${ }^{+}$cells. Furthermore, $\sim 50 \%$ of the administered bacteriae $\left(10^{9} \mathrm{cfu}\right)$ were cleared from the nose within half an hour of administration and could be detected in local draining LNs by $35 \mathrm{~min}$. The kinetics would suggest a DCindependent migration of Salmonellae into the draining LN. To further study this, we administered PTX, a known inhibitor of DC migration. This resulted in a significantly greater bacterial retention within the nose at $35 \mathrm{~min}$ and a corresponding reduction in the Salmonella count within the draining LN. This difference between PBS and PTX-administered mice persisted over $12 \mathrm{~h}$. These data suggest a rapid transport of Gramnegative bacteria into the draining LN by the nasal DCs.

To lend clinical relevance to our mouse studies, we studied nasal DCs in human volunteers over a 12 -month period. The goal of our human studies was to define the DC subsets in nasopharyngeal tissue and to determine whether a change in DC frequency is associated with chronic inflammation. Notably, previous studies have described human nasal DCs using a combination of HLA-DR, CD11c, and CD1c expression. ${ }^{48,49}$ Here, by using a detailed, 12-color flow-cytometry panel, we found that in addition to BDCA-2 ${ }^{+}$plasmacytoid DCs, human nose biopsies encompass two other subsets of DCs: a major BDCA- ${ }^{+}$population and a smaller BDCA $-3^{\text {hi }}$ population. Interestingly, patients with CRS had a significantly lower frequency of BDCA-1 ${ }^{+}$DCs than normal individuals, while the BDCA- $3^{\text {hi }}$ DC reduction also trended toward statistical significance. Detailed functional or transcriptomic assessments were limited by the number of cells available to us in this study. However, in many of the human biopsy samples that we studied for DC subsets, microbial studies done as part of clinical care demonstrated a persistence of coagulase-negative staphylococci. This, combined with the observed reduction in BDCA $-1^{+}$and BDCA- $3^{\text {hi }}$ DCs in CRS, makes us hypothesize that a reduction in DCs, the key antigen-presenting cells within the nose, may predispose to impaired pathogen clearance and chronic inflammation. An alternative possibility is that nasal DCs may migrate into the draining LN during chronic inflammation, leading to falsely lowered numbers seen in the surgical specimens. ${ }^{22}$ As obtaining tissue from patients before the onset of CRS is impossible, we are unable to test this hypothesis. Finally, although we tried to control for the effect of treatment by a careful analysis of all concomitant medications, it is likely to be that treatment may have confounding effect on our results. It is has been shown that nasal plasmacytoid DC and $\mathrm{mDC}$ subsets are significantly reduced following steroid use $\mathrm{e}^{22}$ and a number of patients in the CRS with nasal polyp group were treated with steroids before surgery. Regardless, further testing of the possibility that reduced nasal DC frequency may impair pathogen clearance from the nose and predispose to CRS may help identify the role of therapeutic vaccination strategies (targeting nasal DCs) to augment immune responses against specific pathogens in the treatment of patients with CRS.

To summarize, in this paper we provide the first detailed phenotypic and functional description of murine nasal DCs and describe a significant decrease in DC number to be associated with chronic naso-pharyngeal inflammation in humans. In doing so, we believe that the present study will direct the design of novel preventative and therapeutic vaccine strategies against human diseases.

\section{METHODS}

\section{Human studies}

Human nasal samples. Human nasal and nasopharyngeal tissues were obtained from patients undergoing otorhinological surgery for clinically indicated reasons at the Mount Sinai Hospital. Clinical details of the patients are listed in Supplementary Table S1. Informed consent was obtained from the patients. All samples were collected according to protocols approved by the Institutional Review Board at the Icahn School of Medicine at Mount Sinai.

Analyses of human nasal DCs. The human nasopharyngeal samples were processed immediately post surgery. The tissue was minced, treated with $0.25 \mathrm{mg} \mathrm{ml}^{-1}$ of collagenase (Sigma-Aldrich, St Louis, $\mathrm{MO}$ ) at $37^{\circ} \mathrm{C}$ for $60 \mathrm{~min}$ and cell isolation was performed. Cells were surface stained with CD45, CD20, CD3, CD335, CD66b, BDCA-1, BDCA-2, BDCA-3, CD14, and Live/Dead Fixable Blue Dead Cell Stain (Life Technologies, Grand Island, NY). Titrated antibodies were added to the cells in $50 \mu \mathrm{l}$ PBS $1 \%$ fetal calf serum for $30 \mathrm{~min}$ at $4{ }^{\circ} \mathrm{C}$. Washed cells were fixed in $2 \%$ formaldehyde and stored at $4{ }^{\circ} \mathrm{C}$ until analysis, which was performed using an LSR II flow cytometer (BD Biosciences, San Jose, CA). The whole sample was acquired and analysis was preformed using Flow Jo 9.1 software (Tree Star, Ashland, OR). To identify human DC subsets, dead cells were excluded and $\mathrm{CD}^{+}{ }^{+}$, $\mathrm{CD}_{20}{ }^{+}, \mathrm{CD}_{335^{+}}, \mathrm{CD}_{66 \mathrm{~b}}{ }^{+}$, and $\mathrm{CD} 14^{+}$cells, i.e., T, B, NK cells, neutrophils, and monocytes were sequentially gated out; three DC populations were identified within the $\mathrm{CD} 45^{+}$mononuclear cells by gating respectively on either BDCA- ${ }^{+}$cells, BDCA- $2^{+}$cells, or BDCA-3 ${ }^{\text {hi }}$ cells.

Fluorescent antibodies used. For human antibodies, we used monoclonal antibodies conjugated to different fluorochromes to antiBDCA-1 (L161, Biolegend, San Diego, CA), anti-BDCA-2 (AC144, Miltenyi Biotec, San Diego, CA), anti-BDCA-3 (AD5-14H12, Miltenyi Biotec), anti-CD45 (HI30, BD Horizon, San Jose, CA). The following antibodies of anti-CD3 (OKT3), anti-CD20 (2H7), anti-CD66b 
(G10F5), and anti-CD335 (9E2) were obtained from Biolegend. The antibody to CD14 (TüK4) was obtained from Invitrogen (Grand Island, NY).

\section{Mouse studies}

Mice. Animal care and experimentation were consistent with guidelines of the US National Institutes of Health and were approved by the Institutional Animal Care and Use Committee of Mount Sinai School of Medicine. C57BL/6 mice (B6) and Balb/c mice were purchased from Taconic Farms (Hudson, NY) or bred at Mount Sinai School of Medicine. CD11c-EYFP reporter mice ${ }^{14}$ were purchased from Jackson Laboratory (Bar Harbor, ME). C57BL/6-Tg(TcraTcrb)425Cbn/J (OT-II) mice were kindly provided by Dr Shu-Hsia Chen (Mount Sinai School of Medicine). $\mathrm{zDC}^{\mathrm{DTR}}$ bone marrow chimeric mice were generously provided by Dr M.C. Nussenzweig ${ }^{39}$ (Rockefeller University). $\mathrm{MM}^{\mathrm{DTR} 41}$ or $\mathrm{C} 57 \mathrm{BL} / 6$ bone marrow chimeric mice were obtained from the laboratory of Dr Daniel Mucida (Rockefeller University). All animals were housed under specific pathogen-free conditions and killed at the indicated time points.

Bone marrow chimeras were created by transferring bone marrow from $\mathrm{zDC}^{\mathrm{DTR}}, \mathrm{MM}^{\mathrm{DTR}}$, and C57BL/6 mice into lethally irradiated WT C57BL/6 mice, to avoid lethality associated with DT treatments of $\mathrm{zDC}^{\mathrm{DTR}}$ or $\mathrm{MM}^{\mathrm{DTR}}$. In brief, 7 -week-old male $\mathrm{C} 57 \mathrm{BL} / 6$ hosts underwent two treatments of 500 rads in an animal $\gamma$-irradiator 3$\mathrm{h}$ apart, and $2.5 \times 10^{6}$ bone marrow cells from 8 - to 12 -week-old $\mathrm{zDC}^{\mathrm{DTR}}, \mathrm{MM}^{\mathrm{DTR}}$, and C57BL/6 (WT) donors, respectively, were transferred intravenously. The resulting mice (referred to herein as $\mathrm{zDC}^{\mathrm{DTR}}, \mathrm{MM}^{\mathrm{DTR}}$, and WT) were housed under specific pathogen-free conditions. The chimeric mice were fully reconstituted and ready for experimental use after 8 weeks.

Isolation of NALT. Mice were euthanized by $\mathrm{CO}_{2}$ inhalation and an incision was made at the angle of the mouth on both sides to open the mouth and expose the palate, using established protocols. ${ }^{23}$ Using curved fine forceps, the NALT bearing hard palate was slowly peeled and immediately embedded in to OCT (optimal cutting temperature; Sakura Finetek, Torrance, CA), and stored at $-80^{\circ} \mathrm{C}$. Nasal sections were cut at $10-\mu \mathrm{m}$ thickness with a Leica cryostat (Leica Microsystems, Buffalo Grove, IL) and stored at $-80^{\circ} \mathrm{C}$.

Histology and immunofluorescence analysis. Nasal cryosections were stained with hematoxylin and eosin and fluorescence-activated cellsorted $\mathrm{CD}_{11 \mathrm{c}^{+} \mathrm{MHCII}}{ }^{+} \mathrm{CD}_{11 \mathrm{~b}^{+}} \mathrm{F} 4 / 80^{-} \mathrm{CD}^{-} 4^{-}$and $\mathrm{CD} 11 \mathrm{c}^{+}$ $\mathrm{MHCII}^{+} \mathrm{CD}_{11 \mathrm{~b}}{ }^{+} \mathrm{F} 4 / 80^{+} \mathrm{CD}^{+}{ }^{+}$nasal cells were centrifuged by cytospin onto glass sides, stained in Wright-Geimsa stain solution. Images were captured by brightfield microscope (Zeiss Axioplan2IE, Carl Zeiss, Thornwood, NY) and AxioVision software (Carl Zeiss). Ten-micrometer nasal sections were briefly air dried, fixed in cold acetone for $15 \mathrm{~min}$, rehydrated in PBS for $10 \mathrm{~min}$, blocked with $5 \%$ bovine serum albumin $/ 0.01 \%$ Tween/PBS for $30 \mathrm{~min}$ at room temperature. Sections were stained in a humidified chamber for 1 or $2 \mathrm{~h}$ at room temperature or overnight at $4{ }^{\circ} \mathrm{C}$ with primary antibodies (Supplementary Table S2), washed with $0.01 \%$ Tween/PBS for $5 \mathrm{~min}$ three times, and stained for $1 \mathrm{~h}$ at room temperature with secondary antibodies. If necessary, fluorochrome-labeled tertiary antibody was applied. $\mathrm{T}$ cells were immunostained with rabbit anti-mouse CD3 followed by anti-rabbit IgG Alexa Fluor 488, B cells with rat anti-mouse B220 followed by anti-rat IgG Alexa Fluor 647, and DCs with hamster anti-mouse CD11c followed by both biotinylated anti-hamster IgG and streptavidin Alexa Flour 555. Epithelial cells were immunostained with rabbit anti-mouse cytokeratin 18 followed by anti-rabbit IgG Alexa Fluor 488 . Endothelial cells, lining lymphatic vessels were stained with rabbit anti-mouse LYVE-1 followed by anti-rabbit IgG Alexa Fluor 488. The longitudinal sections of NALT were stained with rat anti-mouse PECAM-1 followed by anti-rat IgG Alexa Fluor 488. Sections were stained with goat anti-mouse langerin (E17) followed by donkey anti-goat Alexa 488. Sections were mounted in ProLong Gold Antifade Mounting Medium with $4^{\prime}$, 6-diamidinio-2-phenylindole (Life Technologies). Fluorescent images were examined in laser scanning confocal microscope (SP5 DM, Leica Microsystems) and LAS AF software (Leica Microsystems) at the Microscopy Shared Resource Facility of Mount Sinai School of Medicine and epifluorescence microscope (Eclipse Ni-U, Nikon Instruments, Melville, NY) with NIS Elements BR software (Nikon Instruments) at the Immunology Institute of Mount Sinai School of Medicine.

Two-photon microscopy. After euthanizing mice, the NALT and LNs were surgically isolated and transferred to a $25 \times 25 \times 1 \mathrm{~mm}$ imaging chamber (Grace Bio-Labs, Bend, OR) containing RPMI. Two-photon imaging was performed using an Olympus Fluoview FV1200MPE microscope with a $40 \times 0.8$ numerical aperture water-emersion objective lens. For multiphoton excitation and second harmonic generation, a MaiTai Ti:sapphire laser (Newport/Spectra-Physics, Santa Clara, CA) was tuned to 790 and $890 \mathrm{~nm}$ for optimized excitation of mCherry expressing Salmonella and CD11c-eYFP ${ }^{+}$cells, respectively. Emission filters were $420-460$ for second harmonic generation (SHG), 495-540 nm for enhanced yellow fluorescent protein (eYFP), and $575-630 \mathrm{~nm}$ for mCherry. Six to eight $80-\mu \mathrm{m} z$-stacks were acquired for each NALT and two to four $200-\mu \mathrm{m} z$-stacks were acquired for each LN, with 2 - $\mu \mathrm{m} z$-spacing between each optical section $(512 \times 512$ pixels $)$. Three-dimensional reconstruction and image analysis was performed using watershed segmentation algorithms in Imaris (Bitplane, South Windsor, CT), to quantify numbers of mCherry $^{+}$and CD11c-eYFP ${ }^{+}$cells.

Nasal, splenic, and LN single-cell preparation. After euthanizing mice, the entire nose was dissected out using previously reported methods. ${ }^{23}$ The organ was mechanically disrupted by using scissors and transferred to conical tubes. The tissue pieces were re suspended in $10 \mathrm{ml}$ of RPMI containing $0.3 \mathrm{mg} \mathrm{ml}^{-1}$ of collagenase (SigmaAldrich) and shaken at 200 r.p.m. for $60 \mathrm{~min}$ at $37^{\circ} \mathrm{C}$. The tissue suspension was collected and passed through a $70-\mu \mathrm{m}$ cell strainer and the cells were pelleted by centrifugation at 1,600 r.p.m. for $5 \mathrm{~min}$. The nasal cells were then resuspended in RPMI. For analyses of NALT and non-NALT DCs separately, the NALT was dissected out as mentioned in the preceding sections. The remaining nasal tissue and NALT tissue were then collagenase digested as mentioned above.

For spleen cell preparation, ACK lysis of red blood cells was followed by washing twice and filtering undigested fibrous material through a $70-\mu \mathrm{m}$ cell strainer.

For LN single-cell preparation, LNs were isolated and mechanically disrupted. LN single-cell suspensions were prepared by incubation with $400 \mathrm{U} \mathrm{ml}^{-1}$ collagenase $\mathrm{D}$ at $37^{\circ} \mathrm{C}$ for $30 \mathrm{~min}$. Cells were filtered through a $70-\mu \mathrm{m}$ cell strainer.

Nasal DC isolation. Single-cell suspensions were isolated from the nose as described above. Using magnetic beads (Miltenyi Biotec), CD11c ${ }^{+}$ cells were isolated as previously described. ${ }^{50}$ Briefly, the cells were washed in $1 \mathrm{ml}$ of MACS buffer (Miltenyi Biotec) before $30 \mathrm{~min}$ incubation on ice with $\mathrm{CD} 11 \mathrm{c}^{+}$beads. The cellular suspensions were washed twice in MACS buffer and passed through a magnetic column, $\mathrm{CD} 11 \mathrm{c}^{+}$cells were isolated by positive selection, washed, and resuspended in PBS. The subsets of $\mathrm{CD} 11 \mathrm{c}^{+}$enriched cells were

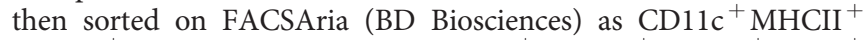

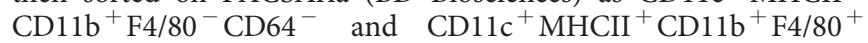
$\mathrm{CD}^{+}{ }^{+}$cells.

Fluorescent antibodies used. We used the following murine antibodies, detailed in Supplementary Table S3, to anti-CD3 (17A2), anti-CD4 (RM4-5), anti-CD8 $\alpha$ (53-6.7), anti-CD103 (M290), anti-Ly6G (1A8), and anti-CD64 (X54-5/7.1) from BD Biosciences; anti-CD11b (M1/70), anti-CD11c (N418), anti-CD45 (30-F11), anti-CD19 
(6D5), anti-F4/80 (BM8), anti-Ly6C (HK1.4), anti-CD24 (M1/69), anti-TLR3 (11F8), anti-TCR V $\alpha 2$ (B20.1), anti-CD14 (Sa14-2), and anti-MMR/CD206 (C068C2) from Biolegend; anti-CD3e (145-2C11), anti-EpCAM (G8.8), anti-CD24 (M1/69), CD115 (AFS98), antiMHCII (M5/114.15.2), anti-CD207 (L31), anti-CD317 (129c), antiCD45R (RA3-6B2), and anti-NK1.1 (PK136) from eBioscience (San Diego, CA). AQUA (L34957) was from Life Technologies and CFSE was from Sigma-Aldrich.

Flow cytometric analyses and gating. Cells were isolated as described above. Before staining, cells were washed and resuspended in staining buffer containing $1 \times$ PBS, $2 \%$ bovine serum albumin, $10 \mathrm{mM}$ EDTA, and $0.01 \% \mathrm{NaN}_{3}$. To block nonspecific staining, the $2.4 \mathrm{G} 2$ anti-CD16/32 antibody was added. Antibodies for cell surface markers were added and cells were incubated for $25 \mathrm{~min}$ at $4{ }^{\circ} \mathrm{C}$. Following the staining, the cells were washed twice and analyzed immediately or fixed in PBS containing $1 \%$ paraformaldehyde and $0.01 \% \mathrm{NaN}_{3}$, and analyzed later on an LSR Fortessa (BD Biosciences), using multiparameter flow cytometry.

For intracellular staining, post-surface staining cells were resuspended in Fixation/Permeablization solution (BD Cytofix/Cytoperm kit, BD Biosciences), and intracellular cytokine staining was performed according to the manufacturer's protocol. Flow cytometric data was analyzed with FlowJo software (Tree Star). Myeloid nasal DC cells were identified by forward and side-scatter characteristics, and dead cells were excluded using Live-dead fixable Aqua (Life Technologies) followed by sequential gating on $\mathrm{CD}_{4} 5^{+}, \mathrm{MHCII}^{+}, \mathrm{CD}_{11 \mathrm{c}^{+}}, \mathrm{CD}_{11 \mathrm{~b}}{ }^{+}$or $\mathrm{CD}_{103}{ }^{+}$, or $\mathrm{CD} 11 \mathrm{~b}^{+} \mathrm{CD} 1103^{+}$double-positive populations.

B16-FLT3L-induced cell expansion in vivo. B16 melanoma cells (B16) and B16 melanoma cells expressing FLT3L (B16-FLT3L) were a provided by Dr Andrew Sikora. Cells were cultured in Dulbecco's modified Eagle's medium containing $10 \%$ fetal calf serum and antibiotics. Mice were injected intradermally with $5-7 \times 10^{6}$ B16 or B16-FLT3L cells. The nasal DC subsets were analyzed 10-14 days later.

Nasal sample processing by mass cytometry. The entire nose from B16 or B16-FLT3L cells implanted mice were processed as described above and stained for CyTOF analysis. All CyTOF-associated reagents were purchased from Fluidigm (Sunnyvale, CA, formerly DVS Sciences). In brief, 5 million cells were stained with a panel of 20 metal-conjugated antibodies (Supplementary Table S4) for $20 \mathrm{~min}$ on ice. All antibodies were either purchased pre-conjugated or conjugated and validated in-house using MaxPar X8 conjugation kits, according to the manufacturer's protocols. The samples were then incubated for $5 \mathrm{~min}$ in cisplatin to identify dead cells, washed, and resuspended in fix/perm buffer containing Ir nucleic acid intercalator to label all nucleated cells. Immediately before analysis, the cells were washed in PBS and $\mathrm{diH}_{2} \mathrm{O}$ and resuspended in $\mathrm{diH}_{2} \mathrm{O}$ containing a 1:10 dilution of EQ 4 Element Calibration beads. After instrument tuning, the samples were acquired on a CyTOF2 Mass Cytometer (Fluidigm) in sequential 10 -min acquisitions at a rate of $<400$ events per second. Following data acquisition, the FCS files were concatenated and normalized using a bead-based normalization algorithm within the CyTOF acquisition software and uploaded to Cytobank for analysis. The FCS files were manually pre-gated on $\mathrm{Ir}-193 \mathrm{DNA}^{+} \mathrm{CD}^{+} 5^{+}$singlets excluding beads, doublets, DNA-negative cell debris, and Pt-195 cisplatin ${ }^{+}$dead cells. The gated population was clustered using spanning-tree progression analysis of density-normalized events. ${ }^{24}$ Cell populations on the spanning-tree progression analysis of density-normalized event trees were manually annotated and based on expression of key markers, while also preserving visualization of unidentified populations within the data set.

In vivo DT treatment. DT purchased from Sigma-Aldrich was prepared in a sterile solution of PBS at a concentration of $1 \mathrm{mg} \mathrm{ml}^{-1}$. DC depletion was effected in $\mathrm{zDC}^{\mathrm{DTR}}$ and $\mathrm{MM}^{\mathrm{DTR}}$ chimeras by a single intraperitoneal injection of $500 \mathrm{ng}$ DT. In addition, WT bone marrow chimeras also received $500 \mathrm{ng}$ DT per mouse. To analyze cell depletion, mice were euthanized $24 \mathrm{~h}$ after DT injection.

In vitro DC: T-cell co-cultures, antigen-presentation assays, and $M L R$. The culture medium used for DC and T-cell cultures was RPMI (Gibco, Grand Island, NY) supplemented with $10 \%$ heat-inactivated fetal calf serum, $2 \mathrm{mM} \mathrm{L}$-glutamine, $100 \mathrm{U} \mathrm{ml}^{-1}$ penicillin, $100 \mu \mathrm{g} \mathrm{ml}^{-1}$ streptomycin, and $5 \mathrm{mM} \beta$-mercaptoethanol (all from Sigma-Aldrich). For antigen-presentation assays, OT-II T cells (for the MLR, T cells from $\mathrm{BALB} / \mathrm{c}$ spleen) were isolated from spleen s of $\mathrm{C} 57 \mathrm{BL} / 6$ mice by excluding $\mathrm{B} 220^{+}, \mathrm{F} 4 / 80^{+}, \mathrm{CD} 49 \mathrm{~b}^{+}$, and I-Ab ${ }^{+}$cells with anti-rat IgG Dynabeads (Life Technologies) and labeled with $5 \mu \mathrm{M}$ CFSE (Life Technologies) for $10 \mathrm{~min}$ at $37^{\circ} \mathrm{C}$. CFSE-labeled $\mathrm{T}$ cells were added to round-bottom microtest wells at $5 \times 10^{4}$ per well and mixed with isolated DCs at a DC:T cell ratio of 1:10, 1:30, and 1:100 in the presence of OVA $\left(25 \mathrm{~g} \mathrm{ml}^{-1}\right.$ final $)$ for antigen-presentation assays. After 5 days, the proliferating $\mathrm{T}$ cells were evaluated by fluorescence-activated cell sorting.

LPS administration and OVA-Alexa Fluor 488. LPS of Escherichia coli was purchased from Sigma-Aldrich and prepared in a sterile solution of PBS at a concentration of $1 \mathrm{mg} \mathrm{ml}^{-1}$. OVA-Alexa Fluor 488 (Life Technologies) was reconstituted at $15 \mu \mathrm{g} \mu \mathrm{l}^{-1}$ with a sterile solution of PBS. One hundred and fifty milligrams of OVA-Alexa Fluor 488 was co-administered with $1 \mu \mathrm{g}$ of LPS in a final volume of $11 \mu \mathrm{l}$ intranasally. Mice were killed at 1, 6, 12, and $24 \mathrm{~h}$ later and nasal tissues, cLN, and mediastinal $\mathrm{LN}$ were examined for $\mathrm{OVA}^{+}$cells.

Infection. For mCherry expressing Salmonella infection, mice were infected intranasally with $10^{9} \mathrm{cfu}$ per mouse. Where specified, $1 \mu \mathrm{g}$ PTX (List Biological Laboratories, Campbell, CA) per mouse was supplemented with Salmonella. Dr Daniel Mucida kindly provided us with mCherry expressing Salmonella. Appearance of infected mice was monitored. Cells from the nose and cervical LNs were analyzed at $5 \mathrm{~min}, 35 \mathrm{~min}$, and $12 \mathrm{~h}$ post infection.

Statistical analysis. Data were entered into a Microsoft Excel database and Prism 6 program (GraphPad Software, La Jolla, CA) was used for quantitative data and statistical analyses. Statistical significance was evaluated using a one-way analysis of variance test followed by a posthoc Bonferroni test with a 95\% confidence interval. Results are expressed as means \pm s.d.

${ }^{\star} P<0.05,{ }^{*} P<0.01$, or ${ }^{*}{ }^{*} P<0.001$ was considered to be statistically significant.

SUPPLEMENTARY MATERIAL is linked to the online version of the paper at http://www.nature.com/mi

\section{ACKNOWLEDGMENTS}

This work was inspired by Dr Ralph Steinman. We thank Dr Maggi Pack for her help with immunofluorescent staining, Dr Michelle Gaylord for her help with tissue processing, and Dr Chae Gyu Park for valuable discussion. This work was supported by grants from the American Gastroenterology Association Elsevier Award (S.M.), The Rockefeller University Clinical and Translation science award pilot project from NIH/NCRR (5UL1RR02414305) National Institutes of Health (S.M. and G.B., grant 8 UL 1 TR000043); B.C. and K.L. grants DP1DA028866 and F31DA036425, respectively, The Leona M. and Harry B. Helmsley Charitable Trust (S.M and G.B), as well as the Crohn's \& Colitis Foundation of America (S.M.)

c) 2015 Society for Mucosal Immunology

\section{REFERENCES}

1. Kurono, Y. et al. Nasal immunization induces Haemophilus influenzaespecific Th1 and Th2 responses with mucosal IgA and systemic IgG antibodies for protective immunity. J. Infect. Dis. 180, 122-132 (1999). 
2. Yanagita, M. et al. Nasopharyngeal-associated lymphoreticular tissue (NALT) immunity: fimbriae-specific Th1 and Th2 cell-regulated IgA responses for the inhibition of bacterial attachment to epithelial cells and subsequent inflammatory cytokine production. J. Immunol. 162 , 3559-3565 (1999).

3. Sandoval, F. et al. Mucosal imprinting of vaccine-induced CD8(+) Tcells is crucial to inhibit the growth of mucosal tumors. Sci. Transl. Med. 5, 172 ra20 (2013).

4. Langermann, S., Palaszynski, S., Sadziene, A., Stover, C.K. \& Koenig, S. Systemic and mucosal immunity induced by BCG vector expressing outersurface protein A of Borrelia burgdorferi. Nature 372, 552-555 (1994).

5. Velge-Roussel, F., Marcelo, P., Lepage, A.C., Buzoni-Gatel, D. \& Bout, D.T. Intranasal immunization with Toxoplasma gondii SAG1 induces protective cells into both NALTand GALT compartments. Infect. Immun. 68, 969-972 (2000).

6. Ruane, D. et al. Lung dendritic cells induce migration of protective Tcells to the gastrointestinal tract. J. Exp. Med. 210, 1871-1888 (2013).

7. Gautier, E.L. et al. Gene-expression profiles and transcriptional regulatory pathways that underlie the identity and diversity of mouse tissue macrophages. Nat. Immunol. 13, 1118-1128 (2012).

8. Imaoka, K. et al. Nasal immunization of nonhuman primates with simian immunodeficiency virus p55gag and cholera toxin adjuvant induces Th1/ Th2 help for virus-specific immune responses in reproductive tissues. J. Immunol. 161, 5952-5958 (1998).

9. Hiroi, T. et al. HIV mucosal vaccine: nasal immunization with rBCG-V3J1 induces a long term V3J1 peptide-specific neutralizing immunity in Th1and Th2-deficient conditions. J. Immunol. 167, 5862-5867 (2001).

10. Kuper, C.F., Hameleers, D.M., Bruijntjes, J.P., van der Ven, I., Biewenga, J. \& Sminia, T. Lymphoid and non-lymphoid cells in nasal-associated lymphoid tissue (NALT) in the rat. An immuno- and enzyme-histochemical study. Cell Tissue Res. 259, 371-377 (1990).

11. Kuper, C.F. et al. The role of nasopharyngeal lymphoid tissue. Immunol. Today 13, 219-224 (1992).

12. Yao, Q., Vuong, V., Li, M. \& Compans, R.W. Intranasal immunization with SIV virus-like particles (VLPS) elicits systemic and mucosal immunity. Vaccine 20, 2537-2545 (2002).

13. Fukuyama, S. et al. Initiation of NALT organogenesis is independent of the IL-7R, LTbetaR, and NIK signaling pathways but requires the Id2 gene and CD3(-)CD4(+)CD45(+) cells. Immunity 17, 31-40 (2002).

14. Lindquist, R.L. et al. Visualizing dendritic cell networks in vivo. Nat. Immunol. 5, 1243-1250 (2004).

15. Wu, Y., Wang, X., Csencsits, K. L., Haddad, A., Walters, N. \& Pascual, D.W. M cell-targeted DNA vaccination. Proc. Natl Acad. Sci. USA. 98, 93189323 (2001).

16. Jeong, K.I., Suzuki, H., Nakayama, H. \& Doi, K. Ultrastructural study on the follicle-associated epithelium of nasal-associated lymphoid tissue in specific pathogen-free (SPF) and conventional environment-adapted (SPF-CV) rats. J. Anat. 196 (Pt 3), 443-451 (2000).

17. Spit, B.J., Hendriksen, E.G., Bruijntjes, J.P. \& Kuper, C.F. Nasal lymphoid tissue in the rat. Cell Tissue Res. 255, 193-198 (1989).

18. Nagatake, T. et al. Id2-, RORgammat-, and LTbetaR-independent initiation of lymphoid organogenesis in ocular immunity. J. Exp. Med. 206, 23512364 (2009).

19. Sosa, G.A. \& Roux, M.E. Development of T lymphocytes in the nasalassociated lymphoid tissue (NALT) from growing Wistar rats. Clin. Dev. Immunol. 11, 29-34 (2004).

20. Costalonga, M., Cleary, P.P., Fischer, L.A. \& Zhao, Z. Intranasal bacteria induce Th1 but not Treg or Th2. Mucosal Immunol. 2, 85-95 (2009).

21. Kiyono, H. \& Fukuyama, S. NALT- versus Peyer's-patch-mediated mucosal immunity. Nat.Rev. Immunol. 4, 699-710 (2004).

22. Hartmann, E. et al. Analysis of plasmacytoid and myeloid dendritic cells in nasal epithelium. Clin. Vaccine Immunol. 13, 1278-1286 (2006).

23. Heritage, P.L., Underdown, B.J., Arsenault, A.L., Snider, D.P. \& McDermott, M.R. Comparison of murine nasal-associated lymphoid tissue and Peyer's patches. Am. J. Respir. Crit. Care Med. 156 (4 Pt 1), 1256-1262 (1997).

24. Qiu, P. etal. Extracting a cellular hierarchy from high-dimensional cytometry data with SPADE. Nat. Biotechnol. 29, 886-891 (2011).

25. Niess, J.H. et al. CX3CR1-mediated dendritic cell access to the intestinal lumen and bacterial clearance. Science 307, 254-258 (2005).
26. Jakubzick, C. et al. Minimal differentiation of classical monocytes as they survey steady-state tissues and transport antigen to lymph nodes. Immunity 39, 599-610 (2013).

27. Banchereau, J. \& Steinman, R.M. Dendritic cells and the control of immunity. Nature 392, 245-252 (1998).

28. Liu, Y.J., Kanzler, H., Soumelis, V. \& Gilliet, M. Dendritic cell lineage, plasticity and cross-regulation. Nat. Immunol. 2, 585-589 (2001).

29. Kataoka, K. et al. The nasal dendritic cell-targeting Flt3 ligand as a safe adjuvant elicits effective protection against fatal pneumococcal pneumonia. Infect. Immun. 79, 2819-2828 (2011).

30. Nacer, A. et al. Imaging murine NALT following intranasal immunization with flagellin-modified circumsporozoite protein malaria vaccines. Mucosal Immunol. 7, 304-314 (2014).

31. Tamoutounour, S. et al. Origins and functional specialization of macrophages and of conventional and monocyte-derived dendritic cells in mouse skin. Immunity 39, 925-938 (2013).

32. Schlitzer, A. et al. IRF4 transcription factor-dependent CD11b + dendritic cells in human and mouse control mucosal IL-17 cytokine responses. Immunity 38, 970-983 (2013).

33. Kataoka, K., McGhee, J.R., Kobayashi, R., Fujihashi, K., Shizukuishi, S. \& Fujihashi, K. Nasal Flt3 ligand cDNA elicits CD11c + CD8 + dendritic cells for enhanced mucosal immunity. J. Immunol. 172, 3612-3619 (2004).

34. Jakubzick, C., Helft, J., Kaplan, T.J. \& Randolph, G.J. Optimization of methods to study pulmonary dendritic cell migration reveals distinct capacities of DC subsets to acquire soluble versus particulate antigen. J. Immunol. Methods 337, 121-131 (2008).

35. Maraskovsky, E. et al. Dramatic increase in the numbers of functionally mature dendritic cells in Flt3 ligand-treated mice: multiple dendritic cell subpopulations identified. J. Exp. Med. 184, 1953-1962 (1996).

36. Fukuiwa, T. et al. A combination of Flt3 ligand cDNA and CpG ODN as nasal adjuvant elicits NALT dendritic cells for prolonged mucosal immunity. Vaccine 26, 4849-4859 (2008).

37. Varmus, H., Klausner, R., Zerhouni, E., Acharya, T., Daar, A.S. \& Singer, P.A. Public health. grand challenges in global health. Science 302, 398-399 (2003).

38. Bendall, S.C. et al. Single-cell mass cytometry of differential immune and drug responses across a human hematopoietic continuum. Science 332, 687-696 (2011).

39. Meredith, M.M. et al. Expression of the zinc finger transcription factor zDC (Zbtb46, Btbd4) defines the classical dendritic cell lineage. J. Exp. Med. 209, 1153-1165 (2012).

40. Satpathy, A.T. et al. Zbtb46 expression distinguishes classical dendritic cells and their committed progenitors from other immune lineages. J. Exp. Med. 209, 1135-1152 (2012)

41. Schreiber, H.A. et al. Intestinal monocytes and macrophages are required for T cell polarization in response to Citrobacter rodentium. J. Exp. Med. 210, 2025-2039 (2013).

42. Steinman, R.M. \& Witmer, M.D. Lymphoid dendritic cells are potent stimulators of the primary mixed leukocyte reaction in mice. Proc. Natl Acad. Sci. USA 75, 5132-5136 (1978).

43. Steinman, R.M. \& Cohn, Z.A. Identification of a novel cell type in peripheral lymphoid organs of mice. I. Morphology, quantitation, tissue distribution. J. Exp. Med. 137, 1142-1162 (1973).

44. Jabbal-Gill, I., Watts, P. \& Smith, A. Chitosan-based delivery systems for mucosal vaccines. Expert Opin. Drug Deliv. 9, 1051-1067 (2012).

45. Nochi, T. et al. Nanogel antigenic protein-delivery system for adjuvant-free intranasal vaccines. Nat. Mater. 9, 572-578 (2010).

46. Bogunovic, M. et al. Origin of the lamina propria dendritic cell network. Immunity 31, 513-525 (2009).

47. Sekine, S. et al. A novel adenovirus expressing Flt3 ligand enhances mucosal immunity by inducing mature nasopharyngeal-associated lymphoreticular tissue dendritic cell migration. J. Immunol. 180, 8126-8134 (2008).

48. Jahnsen, F.L., Gran, E., Haye, R. \& Brandtzaeg, P. Human nasal mucosa contains antigen-presenting cells of strikingly different functional phenotypes. Am. J. Respir. Cell. Mol. Biol. 30, 31-37 (2004).

49. Takano, K. et al. HLA-DR- and CD11c-positive dendritic cells penetrate beyond well-developed epithelial tight junctions in human nasal mucosa of allergic rhinitis. J. Histochem. Cytochem. 53, 611-619 (2005).

50. Ing, R., Segura, M., Thawani, N., Tam, M. \& Stevenson, M.M. Interaction of mouse dendritic cells and malaria-infected erythrocytes: uptake, maturation, and antigen presentation. J. Immunol. 176, 441-450 (2006). 